\title{
The Endocannabinoid System and Pain
}

\author{
Josée Guindon and Andrea G. Hohmann* \\ Neuroscience and Behavior Program, Department of Psychology, University of Georgia, Athens, \\ GA 30602-3013
}

\begin{abstract}
The therapeutic potential of cannabinoids has been the topic of extensive investigation following the discovery of cannabinoid receptors and their endogenous ligands. Cannabinoid receptors and their endogenous ligands are present at supraspinal, spinal and peripheral levels. Cannabinoids suppress behavioral responses to noxious stimulation and suppress nociceptive processing through activation of cannabinoid $\mathrm{CB}_{1}$ and $\mathrm{CB}_{2}$ receptor subtypes. Endocannabinoids, the brain's own cannabis-like substances, share the same molecular target as $\Delta^{9}$-tetrahydrocannabinol, the main psychoactive component in cannabis. Endocannabinoids serve as synaptic circuit breakers and regulate multiple physiological and pathological conditions, e.g. regulation of food intake, immunomodulation, inflammation, analgesia, cancer, addictive behavior, epilepsy and others. This review will focus on uncovering the roles of anandamide (AEA) and 2-arachidonoylglycerol (2-AG), the two best characterized endocannabinoids identified to date, in controlling nociceptive responding. The roles of AEA and 2-AG, released under physiological conditions, in modulating nociceptive responding at different levels of the neuraxis will be emphasized in this review. Effects of modulation of endocannabinoid levels through inhibition of endocannabinoid hydrolysis and uptake is also compared with effects of exogenous administration of synthetic endocannabinoids in acute, inflammatory and neuropathic pain models. Finally, the therapeutic potential of the endocannabinoid signaling system is discussed in the context of identifying novel pharmacotherapies for the treatment of pain.
\end{abstract}

\section{Keywords}

anandamide; 2-arachidonoyl glycerol; FAAH; MGL; endocannabinoid transporter; analgesia; inflammatory; neuropathic pain

\section{INTRODUCTION}

Cannabis has been used for more than twelve thousand years and for many different purposes (i.e. fiber, medicinal, recreational). However, the endocannabinoid signaling system has only recently been the focus of medical research and considered a potential therapeutic target [13]. Endocannabinoids mimic the pharmacological actions of the psychoactive principle of marijuana, $\Delta^{9}$-tetrahydrocannabinol $\left(\Delta^{9}\right.$-THC) [4]. Endocannabinoids are endogenous lipidsignaling molecules. They are generated in the cell membrane from phospholipid precursors and possess cannabimimetic properties because they bind and activate one or more cannabinoid receptor subtypes [5,6]. Endocannabinoids are implicated in different physiological and

\footnotetext{
*Author for Correspondence: Andrea G. Hohmann, Neuroscience and Behavior Program, Department of Psychology, University of Georgia, Athens, GA 30602-3013, Tel: 706-542-2252, Fax: 706-542-3275, ahohmann@uga.edu.

CONFLICT OF INTEREST

The authors state no conflict of interest.
} 
pathological functions (regulation of food intake, immunomodulation, inflammation, analgesia, cancer, addictive behavior, epilepsy and others) [2,7]. The two best-studied endocannabinoids isolated to date are arachidonoylethanolamine (anandamide or AEA) and 2-arachidonoylglycerol (2-AG). AEA is hydrolyzed by the enzyme fatty-acid amide hydrolase (FAAH) whereas 2-AG is degraded by the enzyme monoacylglycerol lipase (MGL) [7,8]. The main goal of this review will be to uncover the role of AEA and 2-AG in pain modulation. This will be accomplished by reviewing studies examining mobilization of endocannabinoids under physiological conditions or by using pharmacological tools that inhibit their uptake or degradation. This review will also consider studies employing exogenous administration of synthetic endocannabinoids in combination with other pharmacological approaches aimed at regulating their uptake or degradation. The overall goal is to understand the physiological role of the endogenous ligands at different levels of the pain pathway and in different models of pathological pain.

\section{CANNABINOID RECEPTOR PHARMACOLOGY}

Cannabinoids produce their effects through the activation of distinct $\mathrm{G}$ protein-coupled receptors identified as the cannabinoid $\mathrm{CB}_{1}[9,10]$ and $\mathrm{CB}_{2}$ receptors [11]. Cannabinoid $\mathrm{CB}_{1}$ and $\mathrm{CB}_{2}$ receptors are members of the superfamily of seven-transmembrane-spanning $\mathrm{G}$ protein-coupled receptors and share $44 \%$ identity at the protein level [11,12]. Similarity increases to $68 \%$ when only the transmembrane region is considered [11,12]. Activation of both cannabinoid receptor subtypes inhibits adenylate cyclase activity by coupling to the $\alpha-$ subunit of the $G$ protein of the $G_{i / o}$ family $\left(G_{i} 1,2\right.$ and 3 , and $G_{o} 1$ and 2$)$ [13]. In contrast to $\mathrm{CB}_{2}$ receptor activation, $\mathrm{CB}_{1}$ receptor activation modulates calcium or potassium conductance $[14,15]$, properties linked to the suppression of neuronal excitability and neurotransmitter release. However, activation of MAPK and Krox-24 expression presumably through the activation of G-protein $\beta \gamma$ subunits is another signalling mechanism recruited by both $\mathrm{CB}_{1}$ and $\mathrm{CB}_{2}$ receptors $[16,17]$. Furthermore, $\mathrm{CB}_{1}$ receptor activation can inhibit type 5- $\mathrm{HT}_{3}$ ion channels [18], modulate the production of nitric oxide [for review see 19,20], alter sodium channel conductance [21] and activate the $\mathrm{Na}^{+} / \mathrm{H}^{+}$exchanger [22]. Signaling mechanisms engaged by activation of $\mathrm{CB}_{1}$ and $\mathrm{CB}_{2}$ receptors have been recently reviewed [13,23].

Cannabinoid $\mathrm{CB}_{1}$ receptors are found mainly in the $\mathrm{CNS}$ and, to a lesser extent, in certain peripheral tissues [24]. At the peripheral level, they are localized in adrenal gland, adipose tissue, heart, liver, lung, prostate, uterus, ovary, testis, bone marrow, thymus, tonsils and presynaptic nerve terminals [12,20,25-27]. Within the brain, they are found in the cerebral cortex, hippocampus (with highest concentrations in the dentate gyrus), amygdala, basal ganglia, substantia nigra pars reticulata, internal and external segment of the globus pallidus and cerebellum (molecular layer) [15,20,24]. More significantly for the purposes of the present review, they are found at central and peripheral levels of the pain pathways [28-32]. The distribution of cannabinoid receptors provides an anatomical basis for the analgesic effects of the cannabinoids. Activation of presynaptic $\mathrm{CB}_{1}$ receptors in different brain regions or on primary afferents inhibits the release of neurotransmitters by decreasing calcium conductance and by increasing the potassium conductance [26].

$\mathrm{CB}_{2}$ receptors are primarily localized to cells of the immune system. $\mathrm{CB}_{2}$ receptors are mainly found in the spleen, tonsils and thymus, tissues responsible for immune cell production and regulation $[11,12,15]$. These immune cells include mast cells, B cells, T4 and T8 cells, microglial cells, macrophages, natural killer cells and, to a lesser extent, monocytes and polymorphonuclear neutrophils $[12,15,33]$. Previous reports suggested that $\mathrm{CB}_{2}$ receptors were absent in neurons of the central nervous system (CNS) $[11,34]$. However, recent studies suggest that they are found in the brain, on dorsal root ganglia, in the lumbar spinal cord, on sensory neurons, on microglia as well as in peripheral tissues [35,36]. 
A better understanding of the role of cannabinoid receptors in different physiological processes has been obtained through research employing pharmacological and genetic tools such as competitive antagonists and knockout mice with disrupted $\mathrm{CB}_{1}[37,38]$ and/or $\mathrm{CB}_{2}$ genes $[39,40]$. Pharmacological evidence also supports the existence of one or more additional receptors for cannabinoids distinct from $\mathrm{CB}_{1}$ and $\mathrm{CB}_{2}$ receptors (reviewed in [41,42]). Of particular recent interest are the GPR55 receptor [43-45] and GPR3, GPR6 and GPR12 which are sphingosine-1-phosphate lipid receptors [46-48]. More work is necessary to determine the connection of novel receptor subtypes such as GPR55 to the endocannabinoid system using more specific compounds and genetic tools.

\section{ENDOCANNABINOIDS}

The discovery of AEA [49], the first endocannabinoid isolated from brain, was followed a few years later by the identification of 2-AG [50,51]. Since then, several putative endocannabinoids have been isolated which include noladin ether [52], virodhamine [53] and Narachidonoyldopamine (NADA) [54,55]. Much less information is known about the endocannabinoid-like properties of these latter putative endogenous ligands (see [56] for a review). Indeed, elucidation of the endogenous function of these compounds in different physiological processes and their precise mechanisms of action requires further investigation [57]. Here, we will consider the roles of different cannabinoid receptors, different endocannabinoids and the machinery responsible for their synthesis and degradation. In some cases, functions of the endocannabinoid system are surmised following pharmacological inhibition of endocannabinoid deactivation. Thus, FAAH and MGL inhibitors increase endocannabinoid accumulation (AEA and 2-AG, respectively) by inhibiting hydrolysis of fatty-acid amides and monoacylglycerols; these enzymes have multiple substrates. Both AEA and 2- $\mathrm{AG}$ are derivatives of arachidonic acid and bind to cannabinoid $\mathrm{CB}_{1}$ and $\mathrm{CB}_{2}$ receptors, although with different affinities and efficacies [58]. However, the variable affinity for cannabinoid receptors may be due, in part, to the existence of distinct binding sites for the different ligands on cannabinoid receptors, as documented by molecular modeling studies [59].

\section{SYNTHESIS AND RELEASE OF AEA AND 2-AG}

Endocannabinoids are produced on demand either by activity-dependent or receptor-stimulated cleavage of membrane phospholipid precursors. Endocannabinoids can be released immediately from cells after their production since they are highly lipophilic and thus are poorly suited for storage (for review see $[8,60,61]$ ). Endocannabinoid signaling is regulated by synthesis, release, uptake and degradation. Membrane depolarization, increases in intracellular calcium levels and receptor stimulation can all activate enzymatic processes leading to the cleavage of membrane phospholipids precursors and subsequent synthesis of endocannabinoids (see $[8,60,61]$ for a review). Different enzymes are implicated in the synthesis of AEA and 2-AG. AEA biosynthesis was originally believed to occur from enzymatic cleavage of a phospholipid precursor, $\mathrm{N}$-arachidonoyl-phosphatidylethanolamine (NAPE). NAPE is synthesized by the enzymatic transfer of arachidonic acid in the sn- 1 position of a phosphatidylcholine to the amide group of a phosphatidylethanolamine under the supervision of the calcium-independent N-acyl-transferase (NAT) [62]. NAPE is then hydrolyzed to AEA by a specific phospholipase D (NAPE-PLD) which has recently been cloned and molecularly characterized [8,63-65]. However, NAPE-PLD knockout mice show no deficit in AEA production, a finding which questions the role of this enzyme in anandamide biosynthesis [66]. Thus, multiple enzymatic pathways may be involved in the biosynthesis of anandamide and NAPE-PLD is unlikely to exclusively control its' biosynthesis [66,67]. 2-AG is synthesized in a two step process. First, the 2-AG precursor diacylglycerol (DAG) is formed from enzymatic cleavage of membrane phospholipid precursors by the enzyme phospholipase 
$\mathrm{C}$ (PLC) (for review see $[68,69])$. DAG is subsequently hydrolyzed by a diacylglycerol lipase (DAGL) selective for the sn-1 position to generate 2-AG [8,68,70,71]. A detailed review of these processes is available [7,60,61] (see Fig. 1). Subsequent to their on-demand synthesis, endocannabinoids may activate cannabinoid receptors following their release into the extracellular space or their movement directly into the cell membrane [72]. AEA preferentially binds to $\mathrm{CB}_{1}$ receptors in vitro, and exhibits low affinity for the transient receptor potential vanilloid 1 (TRPV1) [73-76]. 2-AG is known to activate both $\mathrm{CB}_{1}$ and $\mathrm{CB}_{2}$ receptors [50, 51]. This compound is found in the brain in concentrations 170 -fold higher than those of anandamide [77]. A role for endogenous $2-\mathrm{AG}$ in pain modulation has only recently been described [78,79].

In addition to activating metabotropic $\mathrm{CB}_{1}$ receptors, $\mathrm{AEA}$ can also activate ionotropic TRPV1 receptors as an endovanilloid. TRPV1 receptors are expressed in nociceptive sensory neurons and can detect/respond to noxious mechanical, thermal (i.e. heat) and chemical (i.e. capsaicin) stimuli [73,75,80-83]. Capsaicin and AEA share the same binding site [84], but AEA must be found at high concentrations to activate TRPV1 receptors. Activation of TRPV1 receptors increases intracellular levels of cations such as $\mathrm{Ca}^{2+}$ and depolarizes the cell; these effects can also liberate calcitonin gene-related peptide (CGRP) and substance $\mathrm{P}$ to produce vasodilatation [73]. At high concentrations, AEA can thus exert opposing effects through activation of cannabinoid and TRPV1 receptors, respectively. A functional relationship exists between TRPV1 and $\mathrm{CB}_{1}$ receptors in dorsal root ganglia [85], spinal cord and brain [86] and wherever these two receptors may be co-expressed in the same cell. Antagonists of TRPV1 receptors are implicated in anxiolytic effects in the brain [82]. Peripheral and central TRPV1 receptors therefore remain a viable therapeutic target.

\section{UPTAKE OF ENDOCANNABINOIDS}

Reuptake of endcannabinoids, and most notably anandamide, in the synaptic space may be facilitated by a transporter that has yet to be molecularly cloned. Pharmacological inhibitors for endocannabinoid transport have nonetheless been developed (AM404, VDM11, and others) $[7,74,87,88]$. AEA may accumulate in neurons and other cells by facilitated diffusion rather than employing a specific transport mechanism [89,90]. This process is saturable, temperaturedependent, does not require ATP and is driven by a transmembrane concentration gradient. The existence of a specific endocannabinoid transporter remains controversial, and new discoveries are necessary to establish beyond doubt the mechanism of endocannabinoid transport [90-93]. However, it is noteworthy that AEA uptake is selectively inhibited by a variety of pharmacological agents, consistent with the existence of a saturable component in the transport of anandamide [87,94-96] (see Fig. 1).

Since endocannabinoids are produced on demand and can be released immediately from cells, they can regulate synaptic transmission, both excitatory and inhibitory. In the CNS, endocannabinoids act as neurotransmitters. Endocannabinoids are released from depolarized postsynaptic neurons and travel to presynaptic terminals where they activate $\mathrm{CB}_{1}$ receptors through a retrograde signaling mechanism [97-100] (see Fig. 1). The general effect is a decrease in the release of neurotransmitters such as $\operatorname{GABA}$ ( $\gamma$-amino butyric acid) or glutamate. This retrograde signaling mechanism suggests an important modulatory role for endocannabinoids in controlling neuronal excitability and maintaining homeostasis [101].

\section{DEGRADATION OF AEA AND 2-AG}

Endocannabinoid signaling is limited by efficient degradation processes involving enzymatic hydrolysis mediated by specific intracellular enzymes. The enzymes which degrade endocannabinoids are quite well characterized and include fatty-acid amide hydrolase (FAAH) and monoacylglycerol lipase (MGL) ([60,61], for a review). Inhibitors for FAAH (AM374, 
URB597, URB532 and others) or MGL (URB602, OMDM169, JZL184 and Compound 11) enzymes have been described ([102]; see [7,103] for a review), although selectivity of some agents may vary considerably. FAAH hydrolyzes AEA and related compounds [103-105] whereas MGL metabolizes 2-AG [106,107]. FAAH, a membrane bound enzyme, hydrolyzes AEA in neurons and astrocytes into breakdown products arachidonic acid and ethanolamine $[104,108]$. The distribution of FAAH in organs of the rat has been described in detail; its activity is highest in the liver followed by the small intestine, brain, and testis (see [109] for a review). Immunohistochemical studies have mapped the distribution of FAAH in the brain. FAAH is found in the termination zone of the spinothalamic tract in the ventral posterior lateral nucleus of the thalamus [110-112]. This pathway is implicated in the transmission of nociceptive information to the brain (for review see [113]). FAAH has also been found in Lissauer's tract, in neurons of the superficial dorsal horn of the spinal cord and in dorsal root ganglion cells.

Although FAAH can hydrolyze 2-AG in vitro [114], MGL is the predominant enzyme which controls 2-AG hydrolysis. MGL, a serine hydrolase, hydrolyzes 2-AG into breakdown products (arachidonic acid and glycerol). MGL is located on presynaptic $[60,78,106]$ whereas FAAH is found on post-synaptic $[60,103]$ neurons. Northern blot, immunohistochemical and in situ hybridization techniques have demonstrated that MGL, a presynaptic enzyme, is heterogeneously distributed in the rat brain with the highest levels observed in regions expressing $\mathrm{CB}_{1}$ receptors, such as the cortex, thalamus, hippocampus and cerebellum [106]. MGL is localized exclusively to axon terminals, where it colocalizes with $\mathrm{CB}_{1}$ [115]. By contrast, FAAH is a postsynaptic enzyme and may regulate AEA levels near sites of synthesis $[60,103]$. Although the biosynthesis and metabolism of AEA and 2-AG have been simplified here to maintain the focus of this review, it is important to mention that, in addition to hydrolysis, alternative metabolic pathways exist [67,116-118]. For example, in addition to undergoing hydrolysis, endocannabinoids undergo oxidative metabolism, through which they are transformed into other biologically active mediators [119]. Indeed, there is evidence for the metabolism of AEA and 2-AG by cyclooxygenase (COX), lipoxygenase (LOX) and cytochrome $\mathrm{P} 450$ enzymes, further adding to the complexity of endocannabinoid signalling mechanisms [116,117,120,121].

\section{ENDOCANNABINOIDS IN PAIN PATHWAYS}

Cannabinoid receptors, endocannabinoids, and enzymes controling their synthesis and degradation are localized to multiple levels of the neuraxis, from the periphery to the CNS ([122]; for review see [123]). The discovery of the endocannabinoid system, the availability of antagonists for cannabinoid receptors $\left(\mathrm{CB}_{1}\right.$ and $\left.\mathrm{CB}_{2}\right)$ and the generation of knockout mice lacking $\mathrm{CB}_{1}$ and/or $\mathrm{CB}_{2}$ and $\mathrm{FAAH}$ have spurred research in this growing field. Sites of action for endocannabinoids in suppressing pain were initially suggested by studies employing synthetic cannabinoids targeted at $\mathrm{CB}_{1}$ and/or $\mathrm{CB}_{2}$ receptors. These studies have been recently reviewed [123-126].

\section{SUPRASPINAL LEVEL}

The antinociceptive [127] and electrophysiological [128] effects produced by the systemic administration of cannabinoids are attenuated following spinal transaction. These studies implicate an important role for supraspinal sites in contributing to cannabinoid analgesic action. Direct support for supraspinal sites of cannabinoid analgesic action was derived from studies injecting synthetic cannabinoid agonists intraventricularly and locally into various brain regions (for review see [126]). Structures targeted include the periaqueductal gray (PAG) $[129,130]$, thalamus [131], rostral ventromedial medulla (RVM) [132,133] and amygdala $[134,135]$, among others. These studies have permitted the identification of brain regions responsible for the antinociceptive properties of cannabinoids. Activation of these sites by endocannabinoids may, therefore, produce antinociception under physiological conditions. 
Neurophysiological studies by Walker's laboratory first documented that cannabinoids suppress nociceptive processing ([131,132,136]; see [126] for a review). Cannabinoids, administered systemically, suppress activity of nociceptive neurons in the spinal dorsal horn [136] and ventralposterior lateral nucleus of the thalamus, without altering the activity of purely nonnociceptive neurons [131]. Importantly, these neurophysiological effects correlate highly with the antinociceptive effects of cannabinoids, and cannot be attributed to the motor effects of the same compounds [131].

Walker's group first identified a role for endogenous AEA, released under physiological conditions, in pain modulation [137]. Electrical stimulation of the dorsolateral PAG produced antinociception in the tail-flick test and mobilized endogenous AEA, as measured by microdialysis. Importantly, this stimulation-produced analgesia was blocked by the $\mathrm{CB}_{1}$ antagonist SR141716A, demonstrating mediation by $\mathrm{CB}_{1}$. Intraplantar administration of formalin was also shown to increase levels of endogenous AEA in the dorsolateral PAG. Thus, noxious stimulation may produce endocannabinoid mobilization [137]. Exposure to an environmental stressor (brief continous footshock) also produces endocannabinoid-mediated stress-induced analgesia that is associated with mobilization of endogenous 2-AG and anandamide [78]. Endocannabinoid mobilization was most pronounced in dorsal midbrain fragments containing the intact PAG [78]. Endocannabinoid-mediated stress-induced analgesia is blocked by $\mathrm{CB}_{1}$ but not by $\mathrm{CB}_{2}$ antagonists and is insensitive to blockade by opioid (i.e. with naltexone) and TRPV1 (i.e. with capsazepine) antagonists [78,138]. Moreover, 2AG mobilization in the PAG correlates highly with endocannabinoid-mediated stress antinociception [139]. These observations are also consistent with the ability of systemic and locally administered FAAH inhibitors (e.g. URB597, arachidonoylserotonin), endocannabinoid uptake inhibitors (e.g. VDM11) and locally administered MGL inhibitors (URB602) to enhance endocannabinoid-mediated stress antinociception through a $\mathrm{CB}_{1^{-}}$ dependent mechanism $[78,79,138]$. These effects were all observed at doses that do not alter basal nociceptive thresholds. In the case of URB602, which is not appropriate for systemic use as a selective MGL inhibitor, biochemical studies confirmed that URB602, injected into the PAG, increased levels of 2-AG selectively without altering levels of AEA [78]. These studies collectively suggest a functional role for endogenous AEA and 2-AG in suppressing pain under physiological conditions.

Exogenous cannabinoids also modulate activity of ON and OFF cells in the rostral ventromedial medulla; here, inactivation of the RVM suppresses exogenous cannabinoid antinociception [133]. Pharmacological inactivation of the RVM also suppresses endocannabinoid-mediated analgesia in a rodent model of stress-induced analgesia [138]. Endocannabinoid-mediated stress-induced analgesia is also enhanced in a $\mathrm{CB}_{1}$-dependent manner by intra-RVM administration of a FAAH inhibitor, administered at doses that do not alter the basal nociceptive threshold [138]. These studies support a role for endogenous AEA in the RVM in endocannabinoid-mediated analgesia, although a role for 2-AG has not been assessed.

Endocannabinoid levels are altered following nerve injury in specific brain regions implicated in cannabinoid antinociceptive mechanisms. For example, injury of the sciatic nerve increases AEA and 2-AG levels in the PAG and RVM [140], structures implicated in both the descending modulation and the descending facilitation of pain (see [113] for review). AEA levels were also increased in the dorsal raphe following chronic constriction injury (CCI) [140,141].

Systemic administration of inhibitors of endocannabinoid uptake (VDM-11, OMDM-2, UCM-707 and LY2318912) increases AEA and/or 2-AG levels in brain [93,142]. Interestingly, FAAH inhibition by $\mathrm{N}$-arachidonoyl-serotonin (AA-5-HT) was shown to increase brain levels 
of AEA and 2-AG [142]. These studies suggest that inhibitors of endocannabinoid uptake and deactivation show therapeutic potential for increasing endocannabinoid levels.

\section{SPINAL LEVEL}

Intrathecal administration of cannabinoids produces antinociception [143-145], and suppresses nociceptive neuronal activity [146]. These studies initially documented the existence of spinal sites of cannabinoid antinociceptive actions. Indeed, behavioral [143,145], electrophysiological [146-148] and neurochemical [128,149] studies have demonstrated that cannabinoids act at the spinal level to modulate pain. Mixed cannabinoid agonists such as levonantradol [145], WIN55,212-2 [150] and CP,55,940 [151], at the spinal level, produce $\mathrm{CB}_{1}$-mediated antinociceptive effects. Moreover, cannabinoids suppress $\mathrm{C}$-fiber-evoked responses of dorsal horn neurons recorded in normal, inflamed and nerve injured rats [152155]. Furthermore, these data are consistent with the ability of cannabinoids to suppress Fos protein expression, a neurochemical marker of sustained neuronal activation, in different animal models of persistent pain through $\mathrm{CB}_{1}$ and $\mathrm{CB}_{2}$-specific mechanisms [128,156-159]. Cannabinoid receptors have been demonstrated on primary afferents neurons at pre- and postsynaptic sites in the spinal cord using receptor binding and quantitative autoradiography $[160,161]$. In the dorsal horn of the spinal cord, $\mathrm{CB}_{1}$ receptors have been found on interneurons [29] and on astrocytes [162].

Upregulation of cannabinoid receptors is also observed in the spinal cord following nerve injury $[150,163]$, suggesting that both endocannabinoids and their receptors are regulated under conditions of injury. Exposure to an acute environmental stressor increases 2-AG, but not anandamide, accumulation in the lumbar spinal cord; $2-\mathrm{AG}$ accumulation in the spinal cord correlates highly with the appearance of stress antinociception [79]. Intrathecal administration of inhibitors of both FAAH (URB597/AA5-HT) and MGL-preferring (URB602) also enhance endocannabinoid-mediated stress-induced analgesia through a $\mathrm{CB}_{1}$-dependent mechanism.

AEA and 2-AG are also increased in the spinal cord following induction of a neuropathic pain state produced by CCI of the sciatic nerve [140]. The endocannabinoid system is similarly modulated in response to a spinal cord contusion in rats [164]. The early stages are marked by increases in AEA levels, upregulation of the synthetic enzyme NAPE-PLD, and downregulation of the degradative enzyme FAAH. The delayed stages are marked by increases in 2-AG, a marked upregulation of the 2-AG synthesizing enzyme DAGL- $\alpha$ (i.e. in neurons, astrocytes and immune infiltrates), and a moderate increase in levels of the degradative enzyme MGL [164]. In this study, $\mathrm{CB}_{1}$ receptors were expressed in neurons, oligodendrocytes, and astrocytes, whereas $\mathrm{CB}_{2}$ receptors were strongly upregulated after the lesion and expressed mainly in immune infiltrates and astrocytes [164]. These studies highlight the importance of the endocannabinoid system as a potential therapeutic target for treatment of both spinal cord injury and neuropathic pain.

\section{PERIPHERAL LEVEL}

Peripheral antinociceptive actions of cannabinoids have been demonstrated in numerous animal pain models (for review see [123-125]). Harnessing these mechanisms shows considerable promise for separating the therapeutic effects of cannabinoids from unwanted CNS side-effects. Cannabinoid receptors are synthesized in dorsal root ganglion (DRG) cells, which are the source of primary afferent input to the spinal cord [30,31,85,165-167]. These afferent nerve fibers transmit information about sensory stimulation to the spinal cord, thereby enabling communication between the periphery and specific areas of the CNS that contribute to pain perception $[168,169]$. Following the induction of neuropathy (by spinal nerve ligation), cannabinoid receptors and their endogenous ligands (AEA and 2-AG) are increased in the DRG on the ipsilateral side of the injury [170]. Cannabinoid $\mathrm{CB}_{1}[30,31,85,162]$ and $\mathrm{CB}_{2}$ receptors 
[165,167] are also found in the DRG. DRG cells synthesize cannabinoid receptors, and transport them to peripheral terminals of primary afferents [30,31]. Multiple approaches support the presence of cannabinoid receptors on primary afferent neurons [85,166,171]. $\mathrm{CB}_{1}$ and $\mathrm{CB}_{2}$ receptors are found in large myelinated and small unmyelinated human cutaneous nerve fibers [166]. Both cannabinoid receptor subtypes have also been found in different layers of the skin, and in some adnexal structures (sweat glands, sebaceous cells and others) which may contribute to peripheral antinociceptive actions [166,172-175]. Endocannabinoid levels and FAAH activity have also been measured in rodent paw skin [176-179]. AEA is observed in paw tissue [177-178] whereas a decrease in FAAH activity is observed in the inflamed paw following carrageenan-induced inflammation [179]. In the formalin model, 2-AG hydrolysis inhibitor, OMDM169, increased levels of 2-AG, but not AEA, in the ipsilateral paw [180].

However, Beaulieu and collaborators did not find an increase in AEA and 2-AG levels in the formalin test, measured $2 \mathrm{~h}$ after formalin injection when pain behavior has subsided [176]. In a model of bone cancer pain, intraplantar administration of exogenous AEA or the FAAH inhibitor URB597 increased the local level of AEA [181]. These studies suggest that manipulation of peripheral endocannabinoids may be promising strategy for the management of pain.

\section{MODULATION OF THE ENDOCANNABINOID SYSTEM IN ANIMAL MODELS}

Studies evaluating the presence of hypersensitivity to pain (hyperalgesia) following pharmacological blockade of $\mathrm{CB}_{1}$ receptors provided early physiological support for the hypothesis that endocannabinoids suppress pain. Hyperalgesia has been observed in the hotplate test following intrathecal administration of the $\mathrm{CB}_{1}$ antagonist/inverse agonist SR141716A, and these effects are mimicked by $\mathrm{CB}_{1}$ antisense knockdown at the spinal level $[182,183]$. Pharmacological blockade of $\mathrm{CB}_{1}$ receptors with SR141716A has also been reported to produce hyperalgesia in the formalin test $[177,184]$. However, these findings have not been observed by all investigators [176], suggesting that differences in the level of endogenous analgesic tone may contribute to differences between the studies (see [126] for review). Moreover, the inverse agonist properties of SR141716A complicate interpretation of studies attempting to unmask tonic endocannabinoid activity using competitive antagonists.

Therefore, documentation of intrinsic effects of endocannabinoids released under physiological conditions is critical for understanding the functional roles of endocannabinoids in nociceptive processing. As described above, studies employing stimulation-produced analgesia and stress-induced analgesia provide direct support for the hypothesis that endogenous AEA and 2-AG suppress pain through a $\mathrm{CB}_{1}$-dependent mechanism. In these studies, the tail-flick test was used to quantify the impact of electrical brain stimulation or exposure to footshock stress on antinociception. Thus, it is important to emphasize that treatment with $\mathrm{CB}_{1}$ antagonists $[79,128,137,138,160]$ or modulators of endocannabinoid transport or deactivation $[79,128,138,160]$ lacked intrinsic effects in the tail-flick test in the absence of a stimulus to trigger endocannabinoid mobilization (i.e. brain stimulation or footshock exposure). Thus, it is important to emphasize that tail-flick stimulation is not the trigger for endocannabinoid mobilization in these studies, and antagonists do not alter basal nociceptive thresholds under testing conditions. A role for $\mathrm{CB}_{2}$ was not evaluated in studies of endocannabinoid-mediated stimulation-produced analgesia, presumably due to the lack of availability of a $\mathrm{CB}_{2}$ antagonist at the time the work was conducted [137]. Stress-induced analgesia is also $\mathrm{CB}_{1}$-mediated; it is blocked by multiple $\mathrm{CB}_{1}$ antagonists, involves the mobilization of endocannabinoids at supraspinal (2-AG and AEA; [78]) and spinal (2-AG alone; [79]) levels and is enhanced by inhibitors of endocannabinoid deactivation (URB597, AA-5-HT, URB602) or transport (VDM11). The failure of a $\mathrm{CB}_{2}$ antagonist to block endocannabinoid-mediated stress-induced analgesia in these studies [78] may reflect the absence of a $\mathrm{CB}_{2}$-mediated component in endocannabinoid-mediated stress analgesia or, 
alternately, the failure of the spinally-mediated tail-flick test to detect a $\mathrm{CB}_{2}$-mediated component of endocannabinoid analgesia. The existence of a cross-tolerance and crosssensitization between exogenous cannabinoid antinociception and endocannabinoid-mediated stress-induced analgesia suggests that these phenomena are linked by a common mechanism [185]. The development of drugs that inhibit the enzymatic degradation of endocannabinoids (i.e. through inhibition of FAAH or MGL) or their transport has improved our understanding of the functional roles of the endocannabinoid system in modulating pain under physiological conditions.

Effects of exogenous administration of endocannabinoids (focusing on AEA and 2-AG) and their modulation in models of acute, inflammatory and neuropathic pain models are reviewed below. However, one limitation of studies employing exogenous endocannabinoids is that they do not demonstrate that the endogenous ligands play similar roles under physiological conditions.

\section{ACUTE NOCICEPTION}

Exogenous administration of endocannabinoids or their modulation via inhibition of endocannabinoid deactivation or uptake can produce antinociception in acute pain models (see Table 1 and Table 2). The magnitude of the observed antinociceptive effect may differ depending upon the assay, the endocannabinoid used and/or the mechanism employed to alter endocannabinoid levels. The tail flick test examines the latency for a rodent to "flick" its tail away from a radiant heat source [186], or to remove the tail following immersion in hot water (see Table 1). In this test, the endocannabinoid uptake inhibitors (VDM-11 and UCM707) produce $\mathrm{CB}_{1}$-mediated antinociception [187] under conditions in which the endocannabinoid system is activated [78]. Exogenous administration of AEA produces antinociception [188191], although few studies have evaluated whether this effect is mediated by cannabinoid receptors. Several groups have evaluated $\mathrm{C}_{1}$ component in exogenous AEA antinociception [192-194], but other studies have suggested that anandamide produces antinociception through a $\mathrm{CB}_{1}$-independent mechanism [188,191]. All these studies assessed pharmacological specificity using the $\mathrm{CB}_{1}$ antagonist/inverse agonist SR141716A antagonist. Thus, it is important to emphasize that SR141716A acts as an inverse agonist at $\mathrm{CB}_{1}$ receptors and can activate both $\mathrm{CB}_{2}$ and vanilloid TRPV1 receptors, albeit with low affinity (for review see [195]). Moroever, a role for $\mathrm{CB}_{2}$ receptors cannot be discounted from contributing to the antinociceptive effects of exogenous administration of AEA, because mediation by $\mathrm{CB}_{2}$ receptors was not assessed in these studies. MGL (URB602) and FAAH (AA-5-HT, PMSF, PTK, URB597) inhibitors with varying degrees of selectivity also produce antinociceptive effects in the tail flick test $[189,196,197]$, and specifically under conditions in which the endocannabinoid system is activated and basal nociceptive thresholds are not altered by the same treatments ([79,138] for FAAH inhibitors only; [78] for MGL and FAAH inhibitors). In these studies, cannabinoid receptor antagonists directed at $\mathrm{CB}_{1}$ (AA-5-HT, PTK, URB597 and URB602 [7879,138]) or at $\mathrm{CB}_{1} / \mathrm{CB}_{2}$ (URB597 [197]) were used to identify the receptor mechanism underlying these effects. Indeed, studies employing FAAH knockout mice also corroborate the previous results; $\mathrm{CB}_{1}$-mediated component is observed in both the tail immersion and hot plate tests under conditions in which both $\mathrm{CB}_{1}$ and $\mathrm{CB}_{2}$ antagonists were evaluated [198]. The combination of exogenous AEA with FAAH (ibuprofen, indomethacin, PMSF, URB597) inhibitors also produces antinociception $[189,191,196]$ that is mediated by $\mathrm{CB}_{1}$ receptors $[189,191]$.

The hot plate test involves individually placing rodents on a metal surface typically maintained at $52^{\circ} \mathrm{C}$ (Range: $52-58^{\circ} \mathrm{C}$ for these studies) and measures the latency for the rats to exhibit the first sign of pain (i.e. licking the hind paws or jumping) [199] (see Table 2). In this procedure, inhibitors of endocannabinoid uptake (UCM707, OMDM-2, VDM-11) produce 
antinociception, although mediation by cannabinoid receptors has not been assessed using competitive antagonists [200,201]. Moreover, exogenous administration of AEA produces an antinociceptive effect in the hotplate test $[192,202,203]$ that seems to be $\mathrm{CB}_{1}$-mediated [192] (see Table 2). Consistent with this observation, FAAH inhibitors (URB597 and URB532) produce $\mathrm{CB}_{1}$-mediated antinociception [204]. Endocannabinoid uptake inhibitors (UCM707 and OMDM-1) also potentiate the antinociceptive effect of exogenous anandamide at a dose that did not produce an effect when given alone [200,201]. These observations are consistent with the $\mathrm{CB}_{1}$-mediated enhancement of endocannabinoid-mediated stress analgesia produced by the uptake inhibitor VDM11 in the tail-flick test [78].

The plantar test measures the latency for animals to remove their paws from a radiant heat source that is focused onto the plantar surface of the paw through the floor of a glass platform [205]. In this test, the FAAH inhibitor Compound 17 dose-dependently potentiates the effects of exogenous AEA in the plantar test [206]. Finally, exogenous administration of AEA also produces $\mathrm{CB}_{1}$-mediated antinociception in the paw pressure test [207], assessed using the method of Randall and Selitto [208] (see Table 2). A role for cannabinoid $\mathrm{CB}_{2}$ receptors in antinociception in otherwise naive animals has been studied in an attempt to optimize the therapeutic potential of cannabinoid analgesic systems. $\mathrm{CB}_{2}$ agonists show therapeutic potential because they are devoid of the unwanted central side-effects attributed to activation of $\mathrm{CB}_{1}$ receptors ([124] for a review). However, previous studies assessing responsiveness to acute nociceptive stimulation have either not typically examined the role of $\mathrm{CB}_{2}$ in mediating effects linked to endocannabinoids (AEA and 2-AG), or have not supported the involvement of $\mathrm{CB}_{2}$ mechanisms in endogenous analgesia [78]. It is therefore acknowledged that only certain assays (e.g. the plantar test) are likely to be sensitive to detection of $\mathrm{CB}_{2}$-mediated antinociceptive effects in the absence of inflammation or injury (for review see [124]). Thus, animal models of persistent pain are likely to be differentially sensitive to $\mathrm{CB}_{2}$-mediated components of cannabinoid antinociception. Thus, manipulation of endocannabinoid accumulation through inhibition of metabolism or reuptake mechanisms may be employed to elucidate a role for cannabinoid $\mathrm{CB}_{2}$ receptors under conditions of inflammation or injury.

\section{PERSISTENT INFLAMMATORY NOCICEPTION}

Cannabinoids produce antinociception in tissue injury models of persistent pain. Indeed, behavioural, electrophysiological and neurochemical studies all support a role for cannabinoid $\mathrm{CB}_{1}$ and $\mathrm{CB}_{2}$ receptors in modulating inflammatory nociception (for review see [126]). Effects of exogenous administration of endocannabinoids and/or their modulators (i.e. inhibitors of endocannabinoid uptake or hydrolysis) in different inflammatory pain models (formalin, carrageenan, capsaicin, complete Freund's adjuvant,) is discussed separately because the mechanisms underlying the development and maintenance of distinct inflammatory pain states differs (see Table 3 and Table 4).

The formalin test is a well-established model of persistent pain characterized by a transient, biphasic pattern of pain behaviour [209]. The early phase is characterized by acute activation of $\mathrm{C}$ and $\mathrm{A} \delta$ fibers. The late phase involves an inflammatory reaction in peripheral tissue [210], the development of central nervous system sensitization [211,212] and additionally involves activation of primary afferent nociceptors [213]. In the formalin test, endocannabinoid uptake inhibitors (AM404, UCM707, LY2318912, LY2183240, OMDM132) produce antinociception $[93,214,215]$ (see Table 3 ). These antinociceptive effects are mediated either exclusively by $\mathrm{CB}_{1}$ receptors [214,215] or by both $\mathrm{CB}_{1}$ and $\mathrm{CB}_{2}$ receptors [215]. Exogenous AEA produces $\mathrm{CB}_{1}$-dependent antinociception in the formalin test $[177,216]$ whereas exogenous 2-AG predominantly produces $\mathrm{CB}_{2}$-dependent antinociception [217]. The formalin test has also been used to assess antinociceptive effects produced by FAAH inhibitors (MAFP, Flurbiprofen, Ibuprofen, Compound 17, propofol, AA-5-HT, OMDM106, LY2183240 and 
others) $[178,206,215,216,218-220]$. Thus, it is noteworthy that the mechanism of action varies with the compound employed. For example, AA-5-HT [219,220] and LY2183240 produce $\mathrm{CB}_{1}$-mediated antinociception [215] whereas propofol, a widely used general anesthetic, mediates its antinociceptive effects through activation of $\mathrm{CB}_{1}$ and $\mathrm{CB}_{2}$ receptors [221] (see Table 3). FAAH knockout mice also exhibit $\mathrm{CB}_{1}$-mediated hypoalgesia in both phases of the formalin test [198]. However, the nonsteroidal anti-inflammatory drug ibuprofen produces antinociception in the formalin test that is not related to cannabinoid or TRPV1 receptors [216]. Both $\mathrm{CB}_{1}$ and $\mathrm{CB}_{2}$ receptors are implicated in the antinociceptive effects of MGL inhibitors (OMDM169 and URB602) in this test [180,217]. Furthermore, the combination of AEA with nonselective FAAH inhibitors (ibuprofen or rofeocoxib) produces an antinociceptive effect $[178,216]$ that is $\mathrm{CB}_{1}$-mediated [216], whereas the combination of 2AG with URB602 produces antinociception whose mechanism of action remains to be determined [217].

The carrageenan model involves intraplantar injection of the inflammatory agent, carrageenan, which produces paw swelling (edema) and hypersensitivity to mechanical or thermal stimulation [205]. Carrageenan also induces the expression of Fos, a nonspecific marker of neuronal activation, in the lumbar spinal cord [222]. In this model, exogenous administration of anandamide produces antinociception $[183,223,224]$ which is likely to be $\mathrm{CB}_{1}$-mediated [183] (see Table 4). FAAH inhibitors (URB597 and JNJ-1661010) also produce antinociception in this model ([179,225,226] using URB597; [227] using JNJ-1661010). However, this antinociceptive effect is likely to be independent of $\mathrm{CB}_{1}$ receptor activation because a $\mathrm{CB}_{1}$ antagonist failed to reverse the observed antinociceptive effects [179,226]. A role for both $\mathrm{CB}_{2}$ receptors [179] and peroxisome proliferator-activated receptor- $\alpha$ (PPAR- $\alpha$ ) receptors has been implicated in the antinociceptive effects of URB597 in this model [226]. A role for $\mathrm{CB}_{2}$ but not $\mathrm{CB}_{1}$ receptors in thermal anti-hyperalgesic effects exhibited by FAAH knockout mice has also been demonstrated; however, neither $\mathrm{CB}_{1}$ nor $\mathrm{CB}_{2}$ receptors are implicated in the anti-edemic effects of $\mathrm{FAAH}^{-/-}$mice [198]. Although highly specific MGL inhibitors have only recently been described, MGL-selective inhibitors (URB602 and compound 21) nonetheless exhibit antinociception in this model [228,229; respectively), an effect which involves $\mathrm{CB}_{2}$ receptors [228]. However, caution must be exerted in interpreting effects of URB602, which also inhibits FAAH, and thus, is unlikely to act as a selective MGL inhibitor following systemic administration.

Capsaicin, the pungent ingredient in hot chili peppers, produces hypersensitivity to mechanical and thermal stimulation as well as spontaneous pain following intradermal administration [230]. Hyperalgesia evoked in capsaicin model refers to an increase in pain behavior evoked by suprathreshold stimuli and/or a lowered threshold for pain [230,231]. Only one study has assessed antinociceptive effects following exogenous administration of AEA [202] without investigating the cannabinoid $\left(\mathrm{CB}_{1}\right.$ and/or $\left.\mathrm{CB}_{2}\right)$ receptor mechanism of action (see Table 4). Complete Freund's adjuvant (CFA), administered in the plantar hindpaw surface, produces peripheral edema as well as hypersensitivity to mechanical and thermal stimulation in rodents [232-234]. The inflammation appears approximately two hours following injection of complete Freund's adjuvant, produces its maximal effect after six to eight hours and can persist for weeks following injection [233,235]. Exogenous administration of AEA produces antinociception in the CFA model, but this effect does not involve $\mathrm{CB}_{1}$ receptors [207]. A $\mathrm{CB}_{2}$ mechanism of action was not investigated in this study, likely due to the lack of available $\mathrm{CB}_{2}$-selective antagonists at the time of testing. In this model, the antinociceptive effect of the FAAH inhibitor URB597 is mediated by both $\mathrm{CB}_{1}$ and $\mathrm{CB}_{2}$ receptors [236]. Furthermore, AM404, an inhibitor of endocannabinoid uptake, produces $\mathrm{CB}_{1}$-mediated antinociception in the CFA model $[214,237]$ (see Table 4). These observations are consistent with the ability of exogenous anandamide to produce antinociception in other inflammatory pain models (acid 
acetic writhing test, kaolin writhing test, and other models) through a $\mathrm{CB}_{1}$-dependent mechanism [202,238] (see Table 4).

\section{NEUROPATHIC NOCICEPTION}

Animal models of neuropathic pain have been developed to mimic symptoms associated with nerve injury observed clinically. Neuropathic pain can be induced by traumatic nerve injury [239-241], toxic insults and metabolic challenges. Pharmacotherapies used to treat neuropathic pain produce inadequate pain relief and/or unwanted side-effects (for review see [124,242]), which reinforce the importance of identifying and validating novel therapeutic approaches which suppress neuropathic pain, including those targeting the endocannabinoid system (see Table 5). The chronic constriction injury model is a widely used animal model of neuropathic pain that is produced by loosely placing three constrictive ligatures around the common sciatic nerve [239]. In this model, inhibition of endocannabinoid uptake with AM404 produces antinociceptive effects which are mediated by $\mathrm{CB}_{1}[141,214,243,244]$ and partially by $\mathrm{CB}_{2}$ receptors [243]. However, discrepancies between studies are also apparent [214,244] (see Table 5). The endocannabinoid uptake inhibitor VDM1 1 also produces antinociceptive effects, but involvement of cannabinoid receptors in these effects has not been evaluated [243]. FAAH inhibitors (URB597, AA-5-HT, OL-135) also produce antinociception in the CCI model $[219,245]$. The FAAH inhibitor URB597 produces antihyperalgesic effects in this model that are $\mathrm{CB}_{1}$-mediated and partially $\mathrm{CB}_{2}$-mediated. By contrast, another FAAH inhibitor (AA-5$\mathrm{HT}$ ) has been shown to produce antihyperalgesia that is mediated exclusively by $\mathrm{CB}_{1}$ receptors. No genotype differences in pain behavior were observed between $\mathrm{FAAH}^{-/-}$and wildtype mice subjected to a chronic constriction injury [198]. However, nerve injury may promote adaptive changes in these animals because CCI was found to obliterate the phenotypic hypoalgesia displayed by $\mathrm{FAAH}^{-/-}$mice in the tail immersion and hot plate tests [198].

Pharmacological modulation of endocannabinoid levels also suppresses neuropathic pain behavior in other models of surgically-induced traumatic nerve injury. For example, AM404 produces $\mathrm{CB}_{1}$-dependent antinociception [237] in a model of unilateral hind limb neuropathy induced by partial sciatic nerve ligation (PSNL) [240]. Exogenous administration of anandamide similarly produces $\mathrm{CB}_{1}$-dependent antinociceptive effects $[246,247]$ whereas the antinociceptive effects of 2-AG, administered via the same route, are $\mathrm{CB}_{1} / \mathrm{CB}_{2}$ mediated [248] (see Table 5). FAAH inhibitors (URB597, Ibuprofen, Rofecoxib) are also antinociceptive in this model [246,248]. URB597 produces antinociception through a local peripheral mechanism that is mediated by $\mathrm{CB}_{1} / \mathrm{CB}_{2}$ cannabinoid receptors [248]. However, systemic administration of the same compound does not reliably produce antinociception [236]. Moreover, antinociception produced by local injection of ibuprofen and rofecoxib in the paw does not involve $\mathrm{CB}_{1}$ or $\mathrm{CB}_{2}$ cannabinoid receptors [246]. Local administration of URB602 also produces a $\mathrm{CB}_{1} / \mathrm{CB}_{2}$ antinociception in this model [248]. The combination of FAAH or MGL inhibitors with the exogenous administration of endocannabinoids (AEA or 2-AG) also enhances the antinociceptive effects of the putative endocannabinoid [246,248], but the mechanism of action remains to be determined. The combination of AEA with either ibuprofen or rofecoxib produces antinociception that is mediated exclusively by $\mathrm{CB}_{1}$ receptors, although the mechanism of action for these other combinations remains to be investigated [246].

Effects of modulation of the endocannabinoid system on neuropathic pain behavior have recently been evaluated using a spinal nerve ligation model (SNL). Neuropathic pain was induced by ligating the L5 and L6 spinal nerves according to the procedures described by Kim and Chung [241]. In this model, FAAH inhibitors (URB597, Compound 17, JNJ-1661010 and Compound 34) have been studied exclusively $[206,227,249,250]$ (see Table 5). The antinociceptive effects produced by these agents may involve non-cannabinoid receptor mechanisms (e.g. PPAR- $\alpha$ ). However, antinociception produced by URB597 has been shown 
to involve $\mathrm{CB}_{1}$ receptors [249]. Thus, antinociception produced by FAAH/MGL/ endocannabinoid uptake inhibitors are influenced by the compound employed, the animal model used and potentially the level of endocannabinoid tone produced by the injury. Thus, systemic administration of URB597 produces $\mathrm{CB}_{1}$-mediated enhancements of stress antinociception at doses that do not alter basal nociceptive thresholds in the tail flick test (Table 1). However, systematically administered URB597 produces $\mathrm{CB}_{2}$-mediated antinociception in the carrageenan model and $\mathrm{CB}_{1} / \mathrm{CB}_{2}$-mediated antinociception in complete Freund's adjuvant, partial sciatic nerve ligation (local injection) and chronic constriction injury models.

Interpretation of effects of URB602 is more complicated as this compound is not MGLselective, and can inhibit FAAH; URB602 produces $\mathrm{CB}_{2}$-mediated antinociception in the carrageenan model (systemic injection) and $\mathrm{CB}_{1} / \mathrm{CB}_{2}$-mediated antinociception in the formalin test (i.e. following local injection) and partial sciatic nerve ligation (i.e. following local injection) models ( see Table 3-Table 5). Thus, effects of URB602 are only likely to be mediated by MGL under conditions in which it is documented that local administration of URB602 increases 2-AG accumulation without altering levels of AEA [78]. Systemic administration of AM404 produces $\mathrm{CB}_{1}$-mediated antihyperalgesic effects in inflammatory pain models such as complete Freund's adjuvant and formalin models but involves $\mathrm{CB}_{1} / \mathrm{CB}_{2}$ receptors in the $\mathrm{CCI}$ model. Moreover, local exogenous administrations of $2-\mathrm{AG}$ produce $\mathrm{CB}_{2}$-mediated antinociception in the formalin test and $\mathrm{CB}_{1} / \mathrm{CB}_{2}$-mediated antinociception in the partial sciatic nerve ligation model. However, local administration of $A E A$ produces $\mathrm{CB}_{1}$-mediated antinociception in both of these models (see Table 3-Table 5). A local route of agonist administration may unmask $\mathrm{CB}_{2}$-mediated components in the antinociceptive effects produced by pharmacological inhibitors of endocannabinoid uptake and degradation. However, URB597 produces antinociceptive effects with largely consistent pharamacological specificity following either systemic or local routes of administration. It is also important to emphasize that inhibitors of FAAH elevate levels of fatty-acid amides that do not bind to cannabinoid receptors (e.g. palmitoylethanolamine) and have targets (e.g. PPAR- $\alpha$ ) that are distinct from $\mathrm{CB}_{1}$ and $\mathrm{CB}_{2}$ receptors. Thus, the contribution of non-cannabinoid receptor mechanisms of action in the in vivo pharmacological effects of FAAH and MGL inhibitors must also be considered.

\section{LIMITATIONS}

This review focuses on understanding the functional consequences of increasing endocannabinoid accumulation through blockade of endocannabinoid deactivation or transport, with the caveat that many of these agents employed (e.g. FAAH or MGL inhibitors) are not selective for the endocannabinoid system. Moreover, increasing specific endocannabinoids (e.g. anandamide) or fatty-acid amides (e.g. palmiotylethanolamine) can activate other non-cannabinoid receptors (e.g. TRPV1 or PPAR- $\alpha$, respectively). Entourage effects may also be produced by manipulations that elevate levels of endogenous lipid mediators that do not bind to cannabinoid receptors but, nonetheless, compete for the same enzymes for hydrolysis [251]. Thus, not all effects of these modulators can be attributed to actions at cannabinoid receptors, and assessment of pharmacological specificity is critical for interpretation of in vivo actions of any compound. Palmitoylethanolamide (PEA), an endogenous fatty-acid ethanolamide, is an agonist at PPAR- $\alpha$ receptors, but does not bind to cannabinoid receptors [252,253]. However, effects of this compound can nonetheless be blocked by the $\mathrm{CB}_{2}$ antagonist SR144528 [177]. Inhibition of FAAH by URB597 can also produce antinociceptive effects in inflammatory pain models that are mediated by the activation of PPAR- $\alpha$ receptors [225,226,254]. Synergistic interactions between anandamide and GW7647 (PPAR- $\alpha$ agonist) have been demonstrated in the formalin test [255]. Thus, modulation of the endocannabinoid system by FAAH/MGL/uptake inhibitors and their possible interaction with non-cannabinoid receptors requires further investigation. Even 
though increases in endocannabinoid accumulation are produced by inhibition of the degradative enzymes described in this review, differences in selectivity or potency and heretofore uncharacterized off-target effects may complicate interpretation of results. Therefore, the reader should be aware of these limitations when interpreting the results of any specific study.

\section{CONCLUSION}

Endocannabinoids modulate pain under physiological conditions. Pharmacological approaches that enhance levels of endocannabinoids by inhibiting enzymes controling endocannabinoid deactivation or by blocking their reuptake consequently exhibit therapeutic potential. It is clear that the endocannabinoid system is regulated following conditions of injury. Therefore, more work is necessary to better understand the broad consequences of pharmcological approaches that modulate endocannabinoid levels. Inhibition of endocannabinoids deactivation is likely to show a more beneficial and circumscribed spectrum of biological effects compared to direct activation of $\mathrm{CB}_{1}$ receptors; effects of these inhibitors are limited to sites where endocannabinoids are mobilized under physiological conditions in a stimulation-contingent fashion. Limitations to therapeutic approaches which modulate the endocannabinoid system (e.g. in immunosuppressive diseases) should also be considered when assessing the therapeutic potential of any approach. The impact of long term treatment should be assessed. Multimodal approaches combining modulation of endocannabinoid with other conventional analgesics (e.g. NSAIDs) should also be evaluated for their therapeutic potential. Adjunctive approaches show strong promise for improving the efficacy of existing pharmacotherapies for pain and limiting unwanted side-effect profiles.

\section{Acknowledgments}

JG is supported by a Fonds de la Recherche en Santé du Québec (FRSQ) postdoctoral fellowship. AGH is supported by DA021644, DA022478, and DA022702.

\section{ABBREVIATIONS}

2-AG

AA

AA-5-HT

AEA

$\mathrm{Ca}^{2+}$

$\mathrm{CB}_{1}$

$\mathrm{CB}_{2}$

CCI

CGRP

CNS

COX

$\Delta^{9}$-THC

DAG

DAGL

DR 2-arachidonoylglycerol

arachidonic acid

$\mathrm{N}$-arachidonoyl serotonine

anandamide

calcium

cannabinoid receptor 1

cannabinoid receptor 2

chronic constriction injury

calcitonin gene-related peptide

central nervous system

cyclooxygenase

delta 9-tetrahydrocannabinol

diacylglycerol

diacylglycerol lipase

dorsal raphe 


$\begin{array}{ll}\text { DRG } & \text { dorsal root ganglion } \\ \text { ET } & \text { endocannabinoid membrane transporter } \\ \text { FAAH } & \text { fatty acid amide hydrolase } \\ \text { GABA } & \gamma \text {-amino butyric acid } \\ \text { LOX } & \text { lipoxygenase } \\ \text { MAFP } & \text { methyl arachidonyl fluorophosphonate } \\ \text { MAPK } & \text { mitogen-activated protein kinase } \\ \text { MGL } & \text { monoacylglycerol lipase } \\ \text { NADA } & \text { N-arachidonoyldopamine } \\ \text { NAPE } & \text { N-arachidonoyl-phosphatidylethanolamine } \\ \text { NAT } & \text { N-acyl transferase } \\ \text { NT } & \text { not tested } \\ \text { PAG } & \text { periaqueductal gray } \\ \text { PG } & \text { prostaglandins } \\ \text { PLC } & \text { phospholipase C } \\ \text { PLD } & \text { phospholipase D } \\ \text { PMSF } & \text { phenylmethylsulfonyl fluoride } \\ \text { PSNL } & \text { partial sciatic nerve ligation } \\ \text { PTK } & \text { palmitoyltrifluoromethylketone } \\ \text { RVM } & \text { rostral ventromedial medulla } \\ \text { SIA } & \text { stress-induced analgesia } \\ \text { SNL } & \text { spinal nerve ligation } \\ \text { TRPV1 } & \text { transient receptor potential vanilloid 1 }\end{array}$

\section{References}

1. Abel, EL. Marijuana: The first twelve thousand years. New York: Plenum Press; 1980.

2. Di Marzo V, De Petrocellis L. Plant, synthetic, and endogenous cannabinoids in medicine. Annu. Rev. Med 2006;57:553-574. [PubMed: 16409166]

3. Zias J, Stark H, Sellgman J, Levy R, Werker E, Breuer A, Mechoulam R. Early medical use of cannabis. Nature 1993;363:215. [PubMed: 8387642]

4. Gaoni Y, Mechoulam R. Isolation, structure and partial synthesis of an active constituent of hashish. J. Am. Chem. Soc 1964;86:1646-1647.

5. Di Marzo V. 'Endocannabinoids' and other fatty acid derivatives with cannabimimetic properties: biochemistry and possible physiopathological relevance. Biochim. Biophys. Acta 1998;1392:153175. [PubMed: 9630590]

6. Piomelli D. The endocannabinoid system: a drug discovery perspective. Curr. Opin. Investig. Drugs 2005;6:672-679.

7. Pacher P, Batkai S, Kunos G. The endocannabinoid system as an emerging target of pharmacotherapy. Pharmacol. Rev 2006;58:389-462. [PubMed: 16968947]

8. Wang J, Ueda N. Biology of endocannabinoid synthesis system. Prostaglandins Other Lipid Mediat. 2009 in press, PMID: 19126434. 
9. Devane WA, Dysarz FA 3rd, Johnson MR, Melvin LS, Howlett AC. Determination and characterization of a cannabinoid receptor in rat brain. Mol. Pharmacol 1988;34:605-613. [PubMed: 2848184]

10. Matsuda LA, Lolait SJ, Brownstein MJ, Young AC, Bonner TI. Structure of a cannabinoid receptor and functional expression of the cloned cDNA. Nature 1990;346:561-564. [PubMed: 2165569]

11. Munro S, Thomas KL, Abu-Shaar M. Molecular characterization of a peripheral receptor for cannabinoids. Nature 1993;365:61-65. [PubMed: 7689702]

12. Galiègue S, Mary S, Marchand J, Dussossoy D, Carrière D, Carayon P, Bouaboula M, Shire D, Le Fur G, Casellas P. Expression of central and peripheral cannabinoid receptors in human immune tissues and leukocyte subpopulations. Eur. J. Biochem 1995;232:54-61. [PubMed: 7556170]

13. Howlett AC. Cannabinoid receptor signaling. Handb. Exp. Pharmacol 2005;168:53-79. [PubMed: 16596771]

14. Felder CC, Joyce KE, Briley EM, Mansouri J, Mackie K, Blond O, Lai Y, Ma AL, Mitchell RL. Comparison of the pharmacology and signal transduction of the human cannabinoid CB1 and CB2 receptors. Mol. Pharmacol 1995;48:443-450. [PubMed: 7565624]

15. Howlett AC, Breivogel CS, Childers SR, Deadwyler SA, Hampson RE, Porrino LJ. Cannabinoid physiology and pharmacology: 30 years of progress. Neuropharmacology 2004;47:345-358. [PubMed: 15464149]

16. Bouaboula M, Poinot-Chazel C, Bourrie B, Canat X, Calandra B, Rinaldi-Carmona M, Le Fur G, Casellas P. Activation of mitogen-activated protein kinases by stimulation of the central cannabinoid receptor CB1. Biochem. J 1995;312:637-641. [PubMed: 8526880]

17. Bouaboula M, Poinot-Chazel C, Marchand J, Canat X, Bourrie B, Rinaldi-Carmona M, Calandra B, Le Fur G, Casellas P. Signaling pathway associated with stimulation of CB2 peripheral cannabinoid receptor. Involvement of both mitogen-activated protein kinase and induction of Krox-24 expression. Eur. J. Biochem 1996;237:704-711. [PubMed: 8647116]

18. Barann M, Molderings G, Bruss M, Bonisch H, Urban BW, Gothert M. Direct inhibition by cannabinoids of human 5-HT3A receptors : probable involvement of an allosteric modulatory site. Br. J. Pharmacol 2002;137:589-596. [PubMed: 12381672]

19. Howlett AC, Mukhopadhyay S. Cellular signal transduction by AEA and 2 arachidonoylglycerol. Chem. Phys. Lipids 2000;108:53-70. [PubMed: 11106782]

20. Pertwee RG. Pharmacology of cannabinoid CB1 and CB2 receptors. Pharmacol. Ther 1997;74:129180. [PubMed: 9336020]

21. Nicholson RA, Liao C, Zheng J, David LS, Coyne L, Errington AC, Singh G, Lees G. Sodium channel inhibition by AEA and synthetic cannabimimetics in brain. Brain Res 2003;978:194-204. [PubMed: 12834914]

22. Bouaboula M, Bianchini L, McKenzie FR, Pouyssegur J, Casellas P. Cannabinoid receptor CB1 activates the Nap/Hp exchanger NHE-1 isoform via Gi-mediated mitogen activated protein kinase signaling transduction pathways. FEBS Lett 1999;449:61-65. [PubMed: 10225429]

23. Pertwee RG. Cannabinoid receptors and pain. Prog. Neurobiol 2001;63:569-611. [PubMed: 11164622]

24. Herkenham, M. Localization of cannabinoid receptors in brain and periphery. In: Pertwee, RG., editor. Cannabinoid receptors. London: Academic Press; 1995. p. 145-166.

25. Cota D, Marsicano G, Tschop M, Grubler Y, Flachskamm C, Schubert M, Auer D, Yassouridis A, Thöne-Reineke C, Ortmann S, Tomassoni F, Cervino C, Nisoli E, Linthorst AC, Pasquali R, Lutz B, Stalla GK, Pagotto U. The endogenous cannabinoid system affects energy balance via central orexigenic drive and peripheral lipogenesis. J. Clin. Invest 2003;112:423-431. [PubMed: 12897210]

26. Pertwee RG, Ross RA. Cannabinoid receptors and their ligands. . Prostaglandins Leukot. Essent. Fatty Acids 2002;66:101-121. [PubMed: 12052030]

27. Osei-Hyiaman D, DePetrillo M, Pacher P, Liu J, Radaeva S, Batkai S, Harvey-White J, Mackie K, Offertáler L, Wang L, Kunos G. Endocannabinoid activation at hepatic CB1 receptors stimulates fatty acid synthesis and contributes to diet-induced obesity. J. Clin.Invest 2005;115:1298-1305. [PubMed: 15864349]

28. Agarwal N, Pacher P, Tegeder I, Amaya F, Constantin CE, Brenner GJ, Rubino T, Michalski CW, Marsicano G, Monory K, Mackie K, Marian C, Batkai S, Parolaro D, Fischer MJ, Reeh P, Kunos G, 
Kress M, Lutz B, Woolf CJ, Kuner R. Cannabinoids mediate analgesia largely via peripheral type 1 cannabinoid receptors in nociceptors. Nat.Neurosci 2007;10:870-879. [PubMed: 17558404]

29. Farquhar-Smith WP, Egertová M, Bradbury EJ, McMahon SB, Rice AS, Elphick MR. Cannabinoid $\mathrm{CB}(1)$ receptor expression in rat spinal cord. Mol. Cell. Neurosci 2000;15:510-521. [PubMed: 10860578]

30. Hohmann AG, Herkenham M. Cannabinoid receptors undergo axonal flow in sensory nerves. Neuroscience 1999;92:1171-1175. [PubMed: 10426476]

31. Hohmann AG, Herkenham M. Localization of central cannabinoid CB1 receptor messenger RNA in neuronal subpopulations of rat dorsal root ganglia: a double-label in situ hybridization study. Neuroscience 1999;90:923-931. [PubMed: 10218792]

32. Lever IJ, Rice AS. Cannabinoids and pain. Handb. Exp. Pharmacol 2007;177:265-306. [PubMed: 17087127]

33. Pertwee RG. Cannabinoid pharmacology: the first 66 years. Br. J. Pharmacol 2006;147:S163-S171. [PubMed: 16402100]

34. Griffin G, Fernando SR, Ross RA, McKay NG, Ashford ML, Shire D, Huffman JW, Yu S, Lainton JA, Pertwee RG. Evidence for the presence of CB2-like cannabinoid receptors on peripheral nerve terminals. Eur. J. Pharmacol 1997;339:53-61. [PubMed: 9450616]

35. Jhaveri MD, Sagar DR, Elmes SJ, Kendall DA, Chapman V. Cannabinoid CB2 receptor-mediated anti-nociception in models of acute and chronic pain. Mol. Neurobiol 2007;36:26-35. [PubMed: 17952647]

36. Van Sickle MD, Duncan M, Kingsley PJ, Mouihate A, Urbani P, Mackie K, Stella N, Makriyannis A, Piomelli D, Davison JS, Marnett LJ, Di Marzo V, Pittman QJ, Patel KD, Sharkey KA. Identification and functional characterization of brainstem cannabinoid CB2 receptors. Science 2005;310:329-332. [PubMed: 16224028]

37. Ledent C, Valverde O, Cossu G, Petitet F, Aubert JF, Beslot F, Bohme GA, Imperato A, Pedrazzini T, Roques BP, Vassart G, Fratta W, Parmentier M. Unresponsiveness to cannabinoids and reduced addictive effects of opiates in CB1 receptor knockout mice. Science 1999;283:401-404. [PubMed: 9888857]

38. Zimmer A, Zimmer AM, Hohmann AG, Herkenham M, Bonner TI. Increased mortality, hypoactivity, and hypoalgesia in cannabinoid CB1 receptor knockout mice. Proc. Natl.Acad. Sci. USA 1999;96:5780-5785. [PubMed: 10318961]

39. Buckley NE, McCoy KL, Mezey E, Bonner T, Zimmer A, Felder CC, Glass M, Zimmer A. Immunomodulation by cannabinoids is absent in mice deficient for the cannabinoid CB2 receptor. Eur. J. Pharmacol 2000;396:141-149. [PubMed: 10822068]

40. Jarai Z, Wagner JA, Varga K, Lake KD, Compton DR, Martin BR, Zimmer AM, Bonner TI, Buckley NE, Mezey E, Razdan RK, Zimmer A, Kunos G. Cannabinoid-induced mesenteric vasodilation through an endothelial site distinct from CB1 or CB2 receptors. Proc .Natl. Acad. Sci. USA 1999;96:14136-14141. [PubMed: 10570211]

41. Begg M, Pacher P, Batkai S, Osei-Hyiaman D, Offertaler L, Mo FM, Liu J, Kunos G. Evidence for novel cannabinoid receptors. Pharmacol. Ther 2005;106:133-145. [PubMed: 15866316]

42. Kreitzer FR, Stella N. The therapeutic potential of novel cannabinoid receptors. Pharmacol. Ther 2009;122:83-96. [PubMed: 19248809]

43. Johns DG, Behm DJ, Walker DJ, Ao Z, Shapland EM, Daniels DA, Riddick M, Dowell S, Staton PC, Green P, Shabon U, Bao W, Aiyar N, Yue TL, Brown AJ, Morrison AD, Douglas SA. The novel endocannabinoid receptor GPR55 is activated by atypical cannabinoids but does not mediate their vasodilator effects. Br. J. Pharmacol 2007;152:825-831. [PubMed: 17704827]

44. Ryberg E, Larsson N, Sjögren S, Hjorth S, Hermansson NO, Leonova J, Elebring T, Nilsson K, Drmota T, Greasley PJ. The orphan receptor GPR55 is a novel cannabinoid receptor. Br. J. Pharmacol 2007;152:1092-1101. [PubMed: 17876302]

45. Staton PC, Hatcher JP, Walker DJ, Morrison AD, Shapland EM, Hughes JP, Chong E, Mander PK, Green PJ, Billinton A, Fulleylove M, Lancaster HC, Smith JC, Bailey LT, Wise A, Brown AJ, Richardson JC, Chessell IP. The putative cannabinoid receptor GPR55 plays a role in mechanical hyperalgesia associated with inflammatory and neuropathic pain. Pain 2008;139:225-236. [PubMed: 18502582] 
46. Eggerickx D, Denef JF, Labbe O, Hayashi Y, Refetoff S, Vassart G, Parmentier M, Libert F. Molecular cloning of an orphan G-protein-coupled receptor that constitutively activates adenylate cyclase. Biochem. J 1995;309(Pt 3):837-843. [PubMed: 7639700]

47. Kostenis E. Novel clusters of receptors for sphingosine-1-phosphate, sphingosylphosphorylcholine, and (lyso)-phosphatidic acid: new receptors for "old" ligands. J Cell. Biochem 2004;92:923-936. [PubMed: 15258916]

48. Uhlenbrock K, Huber J, Ardati A, Busch AE, Kostenis E. Fluid shear stress differentially regulates gpr3, gpr6, and gpr12 expression in human umbilical vein endothelial cells. Cell. Physiol. Biochem 2003;13:75-84. [PubMed: 12649592]

49. Devane WA, Hanus L, Breuer A, Pertwee RG, Stevenson LA, Griffin G, Gibson D, Mandelbaum A, Etinger A, Mechoulam R. Isolation and structure of a brain constituent that binds to the cannabinoid receptor. Science 1992;258:1946-1949. [PubMed: 1470919]

50. Mechoulam R, Ben-Shabat S, Hanus L, Ligumsky M, Kaminski NE, Schatz AR, Gopher A, Almog S, Martin BR, Compton DR, Pertwee RG, Griffin G, Bayewitch M, Barg J, Vogel Z. Identification of an endogenous 2-monoglyceride, present in canine gut, that binds to cannabinoid receptors. Biochem. Pharmacol 1995;50:83-90. [PubMed: 7605349]

51. Sugiura T, Kondo S, Sukagawa A, Nakane S, Shinoda A, Itoh K, Yamashita A, Waku K. 2Arachidonoylglycerol: a possible endogenous cannabinoid receptor ligand in brain. Biochem. Biophys. Res. Commun 1995;215:89-97. [PubMed: 7575630]

52. Hanus L, Abu-Lafi S, Fride E, Breuer A, Vogel Z, Shalev DE, Kustanovich I, Mechoulam R. 2Arachidonyl glyceryl ether, an endogenous agonist of the cannabinoid CB1 receptor. Proc. Natl. Acad. Sci. USA 2001;98:3662-3665. [PubMed: 11259648]

53. Porter AC, Sauer JM, Knierman MD, Becker GW, Berna MJ, Bao J, Nomikos GG, Carter P, Bymaster FP, Leese AB, Felder CC. Characterization of a novel endocannabinoid, virodhamine, with antagonist activity at the CB1 receptor. J. Pharmacol. Exp. Ther 2002;301:1020-1024. [PubMed: 12023533]

54. Huang SM, Bisogno T, Trevisani M, Al-Hayani A, De Petrocellis L, Fezza F, Tognetto M, Petros TJ, Krey JF, Chu CJ, Miller JD, Davies SN, Geppetti P, Walker JM, Di Marzo V. An endogenous capsaicin-like substance with high potency at recombinant and native vanilloid VR1 receptors. Proc. Natl. Acad. Sci. USA 2002;99:8400-8405. [PubMed: 12060783]

55. Ross HR, Gilmore AJ, Connor M. Inhibition of human recombinant T-type calcium channels by the endocannabinoid N-arachidonoyl dopamine. Br. J. Pharmacol. 2009 PMID:19226289.

56. Bradshaw HB, Walker JM. The expanding field of cannabimimetic and related lipid mediators. Br. J. Pharmacol 2005;144:459-465. [PubMed: 15655504]

57. De Petrocellis L, Cascio MG, Di Marzo V. The endocannabinoid system: a general view and latest additions. Br. J. Pharmacol 2004;141:765-774. [PubMed: 14744801]

58. Howlett AC. The cannabinoid receptors. Prostaglandins Other Lipid Mediat 2002;68-69:619-631.

59. Reggio PH. Pharmacophores for ligands recognition and activation/inactivation of the cannabinoid receptors. Curr. Pharm. Des 2003;9:1607-1633. [PubMed: 12871061]

60. Di Marzo V. Endocannabinoids: synthesis and degradation. Rev. Physiol. Biochem. Pharmacol 2006;160:1-24. [PubMed: 18481028]

61. Di Marzo V. Targeting the endocannabinoid system: to enhance or reduce? Nat. Rev. Drug Discov 2008;7:438-455. [PubMed: 18446159]

62. Jin XH, Uyama T, Wang J, Okamoto Y, Tonai T, Ueda N. cDNA cloning and characterization of human and mouse $\mathrm{Ca}(2+)$-independent phosphatidylethanolamine $\mathrm{N}$-acyltransferases. Biochim. Biophys. Acta 2009;1791:32-38. [PubMed: 19000777]

63. Egertová M, Simon GM, Cravatt BF, Elphick MR. Localization of N-acyl phosphatidylethanolamine phospholipase D (NAPE-PLD) expression in mouse brain: A new perspective on Nacylethanolamines as neural signaling molecules. J. Comp. Neurol 2008;506:604-615. [PubMed: 18067139]

64. Okamoto Y, Morishita J, Tsuboi K, Tonai T, Ueda N. Molecular characterization of a phospholipase D generating anandamide and its congeners. J. Biol. Chem 2004;279:5298-5305. [PubMed: 14634025]

65. Okamoto Y, Wang J, Morishita J, Ueda N. Biosynthetic pathways of the endocannabinoid anandamide. Chem. Biodivers 2007;4:1842-1857. [PubMed: 17712822] 
66. Leung D, Saghatelian A, Simon GM, Cravatt BF. Inactivation of N-acylphosphatidylethanolamine phospholipase D reveals multiple mechanisms for the biosynthesis of endocannabinoids. Biochemistry 2006;45:4720-4726. [PubMed: 16605240]

67. Liu J, Wang L, Harvey-White J, Huang BX, Kim HY, Luquet S, Palmiter RD, Krystal G, Rai R, Mahadevan A, Razdan RK, Kunos G. Multiple pathways involved in the biosynthesis of anandamide. Neuropharmacology 2008;54:1-7. [PubMed: 17631919]

68. Basavarajappa BS. Critical enzymes involved in endocannabinoid metabolism. Protein Pept. Lett 2007;14:237-246. [PubMed: 17346227]

69. Cocco L, Faenza I, Fiume R, Maria Billi A, Gilmour RS, Manzoli FA. Phosphoinositide-specific phospholipase C (PI-PLC) beta1 and nuclear lipid-dependent signaling. Biochim. Biophys. Acta 2006;1761:509-521. [PubMed: 16624616]

70. Bisogno T, Howell F, Williams G, Minassi A, Cascio MG, Ligresti A, Matias I, Schiano-Moriello A, Paul P, Williams EJ, Gangadharan U, Hobbs C, Di Marzo V, Doherty P. Cloning of the first sn1DAG lipases points to the spatial and temporal regulation of endocannabinoid signaling in the brain. J. Cell. Biol 2003;163:463-468. [PubMed: 14610053]

71. Di Marzo V, Bisogno T, De Petrocellis L, Melck D, Orlando P, Wagner JA, Kunos G. Biosynthesis and inactivation of the endocannabinoid 2-arachidonoylglycerol in circulating and tumoral macrophages. Eur. J. Biochem 1999;264:258-267. [PubMed: 10447696]

72. Piomelli D. The molecular logic of endocannabinoid signalling. Nat. Rev. Neurosci 2003;4:873-884. [PubMed: 14595399]

73. Di Marzo V, Bisogno T, De Petrocellis L. Anandamide : some like it hot. Trends Pharmacol. Sci 2001;22:346-349. [PubMed: 11431028]

74. Palmer SL, Thakur GA, Makriyannis A. Cannabinergic ligands. Chem. Phys. Lipids 2002;121:3-19. [PubMed: 12505686]

75. Piomelli D. The ligand that came from within. Trends Pharmacol. Sci 2001;22:17-19. [PubMed: 11165666]

76. Smart D, Gunthorpe MJ, Jerman JC, Nasir S, Gray J, Muir AI, Chambers JK, Randall AD, Davis JD. The endogenous lipid anandamide is a full agonist at the human vanilloid receptor (hVR1). Br. J. Pharmacol 2000;129:227-230. [PubMed: 10694225]

77. Stella N, Schweitzer P, Piomelli D. A second endogenous cannabinoid that modulates long-term potentiation. Nature 1997;388:773-778. [PubMed: 9285589]

78. Hohmann AG, Suplita RL, Bolton NM, Neely MH, Fegley D, Mangieri R, Krey JF, Walker JM, Holmes PV, Crystal JD, Duranti A, Tontini A, Mor M, Tarzia G, Piomelli D. An endocannabinoid mechanism for stress-induced analgesia. Nature 2005;435:1108-1112. [PubMed: 15973410]

79. Suplita RL 2nd, Gutierrez T, Fegley D, Piomelli D, Hohmann AG. Endocannabinoids at the spinal level regulate, but do not mediate, nonopioid stress-induced analgesia. Neuropharmacology 2006;50:372-379. [PubMed: 16316669]

80. Akopian AN, Ruparel NB, Jeske NA, Patwardhan A, Hargreaves KM. Role of ionotropic cannabinoid receptors in peripheral antinociception and antihyperalgesia. Trends Pharmacol. Sci 2009;30:79-84. [PubMed: 19070372]

81. Caterina MJ, Schumacher MA, Tominaga M, Rosen TA, Levine JD, Julius D. The capsaicin receptor: a heat-activated ion channel in the pain pathway. Nature 1997;389:816-824. [PubMed: 9349813]

82. Di Marzo V, Gobbi G, Szallasi A. Brain TRPV1: a depressing TR(i)P down memory lane? Trends Pharmacol. Sci 2008;29:594-600. [PubMed: 18947889]

83. Ross RA. Anandamide and vanilloid TRPV1 receptors. Br. J. Pharmacol 2003;140:790-801. [PubMed: 14517174]

84. Di Marzo V, Blumberg PM, Szallasi A. Endovanilloid signaling in pain. Curr. Opin. Neurobiol 2002;12:372-379. [PubMed: 12139983]

85. Ahluwalia J, Urban L, Capogna M, Bevan S, Nagy I. Cannabinoid 1 receptors are expressed in nocceptive primary sensory neurons. Neuroscience 2000;100:685-688. [PubMed: 11036202]

86. Cristino L, De Petrocellis L, Pryce G, Baker D, Guglielmotti V, Di Marzo V. Immunohistochemical localization of cannabinoid type 1 and vanilloid transient receptor potential vanilloid type 1 receptors in the mouse brain. Neuroscience 2006;139:1405-1415. [PubMed: 16603318] 
87. Beltramo M, Stella N, Calignano A, Lin SY, Makriyannis A, Piomelli D. Functional role of highaffinity anandamide transport, as revealed by selective inhibition. Science 1997;277:1094-1097. [PubMed: 9262477]

88. Di Marzo V, Bifulco M, De Petrocellis L. The endocannabinoid system and its therapeutic exploitation. Nat. Rev.Drug Discov 2004;3:771-784. [PubMed: 15340387]

89. Hillard CJ, Edgemond WS, Jarrahian A, Campbell WB. Accumulation of Narachidonoylethanolamine (anandamide) into cerebellar granule cells occurs via facilitated diffusion. J. Neurochem 1997;69:631-638. [PubMed: 9231721]

90. Hillard CJ, Jarrahian A. Cellular accumulation of anandamide: consensus and controversy. Br. J. Pharmacol 2003;140:802-808. [PubMed: 12970089]

91. Glaser ST, Kaczocha M, Deutsch DG. Anandamide transport: a critical review. Life Sci 2005;77:1584-1604. [PubMed: 15979096]

92. McFarland MJ, Barker EL. Anandamide transport. Pharmacol. Ther 2004;104:117-135. [PubMed: 15518883]

93. Moore SA, Nomikos GG, Dickason-Chesterfield AK, Schober DA, Schaus JM, Ying BP, Xu YC, Phebus L, Simmons RM, Li D, Iyengar S, Felder CC. Identification of a high-affinity binding site involved in the transport of endocannabinoids. Proc. Natl. Acad. Sci. USA 2005;102:17852-17857. [PubMed: 16314570]

94. Bisogno T, Maurelli S, Melck D, De Petrocellis L, Di Marzo V. Biosynthesis, uptake and degradation of anandamide and palmitoylethanolamide in leukocytes. J. Biol. Chem 1997;272:3315-3323. [PubMed: 9013571]

95. Hillard CJ, Jarrahian A. The movement of $N$-arachidonolethanolamide (anandamide) across cellular membranes. Chem. Phys. Lipids 2000;108:123-134. [PubMed: 11106786]

96. Maccarrone M, Bari M, Lorenzon T, Bisogno T, Di Marzo V, Finazzi-Agro A. Anandamide uptake by human endothelial cells and is regulation by nitric oxide. J. Biol. Chem 2000;275:13484-13492. [PubMed: 10788462]

97. Alger BE. Retrograde signaling in the regulation of synaptic transmission: focus on endocannabinoids. Prog. Neurobiol 2002;68:247-286. [PubMed: 12498988]

98. Freund TF, Katona I, Piomelli D. Role of endogenous cannabinoids in synaptic signaling. Physiol. Rev 2003;83:1017-1066. [PubMed: 12843414]

99. Wilson RI, Nicoll RA. Endogenous cannabinoids mediate retrograde signaling at hippocampal synapses. Nature 2001;410:588-592. [PubMed: 11279497]

100. Wilson RI, Nicoll RA. Endocannabinoid signaling in the brain. Science 2002;296:678-682. [PubMed: 11976437]

101. Katona I, Freund TF. Endocannabinoid signaling as a synaptic circuit breaker in neurological disease. Nat. Med 2008;14:923-930. [PubMed: 18776886]

102. Long JZ, Li W, Booker L, Burston JJ, Kinsey SG, Schlosburg JE, Pavón FJ, Serrano AM, Selley DE, Parsons LH, Lichtman AH, Cravatt BF. Selective blockade of 2-arachidonoylglycerol hydrolysis produces cannabinoid behavioral effects. Nat. Chem. Biol 2009;5:37-44. [PubMed: 19029917]

103. Seierstad M, Breitenbucher JG. Discovery and Development of Fatty Acid Amide Hydrolase (FAAH) Inhibitors. J. Med. Chem 2008;51:7327-7343. [PubMed: 18983142]

104. Cravatt BF, Giang DK, Mayfield SP, Boger DL, Lerner RA, Gilula NB. Molecular characterization of an enzyme that degrades neuromodulatory fatty-acid amides. Nature 1996;384:83-87. [PubMed: 8900284]

105. Giang DK, Cravatt BF. Molecular characterization of human and mouse fatty acid amide hydrolases. Proc. Natl. Acad. Sci. USA 1997;94:2238-2242. [PubMed: 9122178]

106. Dinh TP, Carpenter D, Leslie FM, Freund TF, Katona I, Sensi SL, Kathuria S, Piomelli D. Brain monoglyceride lipase participating in endocannabinoid inactivation. Proc. Natl. Acad. Sci. USA 2002;99:10819-10824. [PubMed: 12136125]

107. Dinh TP, Kathuria S, Piomelli D. RNA interference suggests a primary role for monoacylglycerol lipase in the degradation of the endocannabinoid 2-arachidonoylglycerol. Mol. Pharmacol 2004;66:1260-1264. [PubMed: 15272052] 
108. Di Marzo V, Fontana A, Cadas H, Schinelli v, Cimino G, Schwartz JC, Piomelli D. Formation and inactivation of endogenous cannabinoid anandamide in central neurons. Nature 1994;372:686-691. [PubMed: 7990962]

109. Deutsch DG, Ueda N, Yamamoto S. The fatty acid amide hydrolase (FAAH). Prostaglandins Leukot. Essent. Fatty Acids 2002;66:201-210. [PubMed: 12052036]

110. Egertová M, Giang DK, Cravatt BF, Elphick MR. A new perspective on cannabinoid signaling: complementary localization of fatty acid amide hydrolase and the CB1 receptor in rat brain. Proc. Biol. Sci 1998;265:2081-2085. [PubMed: 9842734]

111. Egertová M, Cravatt BF, Elphick MR. Comparative analysis of fatty acid amide hydrolase and CB (1) cannabinoid receptor expression in the mouse brain : evidence of a widespread role for fatty acid amide hydrolase in regulation of endocannabinoid signaling. Neuroscience 2003;119:481-496. [PubMed: 12770562]

112. Tsou K, Nogueron MI, Muthian S, Sañudo-Pena MC, Hillard CJ, Deutsch DG, Walker JM. Fatty acid amide hydrolase is located preferentially in large neurons in the rat central nervous system as revealed by immunohistochemistry. Neurosci. Lett 1998;254:137-140. [PubMed: 10214976]

113. Guindon, J.; Hohmann, AG. Handbook of Neuroscience for the Neural and Behavioral Sciences. Pain: Mechanisms and Measurement. Bernston, Gary G.; Cacioppo, John T., editors. New Jersey: John H. Wiley \& Sons; 2009. in press

114. Goparaju SK, Ueda N, Yamaguchi H, Yamamoto S. Anandamide amidohydrolase reacting with 2arachidonoylglycerol, another cannabinoid receptor ligand. FEBS Lett 1998;422:69-73. [PubMed: 9475172]

115. Gulyas AI, Cravatt BF, Bracey MH, Dinh TP, Piomelli D, Boscia F, Freund TF. Segregation of two endocannabinoid-hydrolyzing enzymes into pre- and postsynaptic compartments in the rat hippocampus, cerebellum and amygdala. Eur. J. Neurosci 2004;20:441-458. [PubMed: 15233753]

116. Alexander SP, Kendall DA. The complications of promiscuity: endocannabinoid action and metabolism. Br. J. Pharmacol 2007;152:602-623. [PubMed: 17876303]

117. Guindon J, Hohmann AG. A physiological role for endocannabinoid-derived products of cyclooxygenase-2-mediated oxidative metabolism. Br. J. Pharmacol 2008;153:1341-1343. [PubMed: 18297102]

118. Jhaveri MD, Richardson D, Chapman V. Endocannabinoid metabolism and uptake: novel targets for neuropathic and inflammatory pain. Br. J. Pharmacol 2007;152:624-632. [PubMed: 17704819]

119. Hu SS, Bradshaw HB, Chen JS, Tan B, Walker JM. Prostaglandin E2 glycerol ester, an endogenous COX-2 metabolite of 2-arachidonoylglycerol, induces hyperalgesia and modulates NFkappaB activity. Br. J. Pharmacol 2008;153:1538-1549. [PubMed: 18297109]

120. Fowler CJ. The contribution of cyclooxygenase-2 to endocannabinoid metabolism and action. Br. J. Pharmacol 2007;152:594-601. [PubMed: 17618306]

121. Snider NT, Kornilov AM, Kent UM, Hollenberg PF. Anandamide metabolism by human liver and kidney microsomal cytochrome p450 enzymes to form hydroxyeicosatetraenoic and epoxyeicosatrienoic acid ethanolamides. J. Pharmacol. Exp. Ther 2007;321:590-597. [PubMed: 17272674]

122. Herkenham M, Lynn AB, Johnson MR, Melvin LS, de Costa BR, Rice KC. Characterization and localization of cannabinoid receptors in rat brain: a quantitative in vitro autoradiographic study. $\mathrm{J}$. Neurosci 1991;11:563-583. [PubMed: 1992016]

123. Hohmann AG. Spinal and peripheral mechanisms of cannabinoid antinociception: behavioural, neurophysiological and neuroanatomical perspectives. Chem. Phys. Lipids 2002;121:173-190. [PubMed: 12505699]

124. Guindon J, Hohmann AG. Cannabinoid CB2 receptors: a therapeutic target for the treatment of inflammatory and neuropathic pain. Br. J. Pharmacol 2008;153:319-334. [PubMed: 17994113]

125. Rice AS, Farquhar-Smith WP, Nagy I. Endocannabinoids and pain: spinal and peripheral analgesia in inflammation and neuropathy. Prostaglandins Leukot. Essent. Fatty Acids 2002;66:243-256. [PubMed: 12052040]

126. Walker JM, Hohmann AG. Cannabinoid mechanisms of pain suppression. Handb. Exp. Pharmacol 2005;168:509-554. [PubMed: 16596786] 
127. Lichtman AH, Martin BR. Spinal and supraspinal components of cannabinoid-induced antinociception. J. Pharmacol. Exp. Ther 1991;258:517-523. [PubMed: 1650831]

128. Hohmann AG, Tsou K, Walker JM. Intrathecal cannabinoid administration suppresses noxious stimulus-evoked Fos protein-like immunoreactivity in rat spinal cord : comparison with morphine. Acta. Pharmacol. Sin 1999;20:1132-1136.

129. Lichtman AH, Cook SA, Martin BR. Investigation of brain sites mediating cannabinoid induced antinociception in rats: evidence supporting periaqueductal gray involvement. J. Pharmacol. Exp. Ther 1996;276:585-593. [PubMed: 8632325]

130. Martin WJ, Patrick SL, Coffin PO, Tsou K, Walker JM. An examination of the central sites of action of cannabinoid-induced antinociception in the rat. Life Sci 1995;56:2103-2109. [PubMed: 7776838]

131. Martin WJ, Hohmann AG, Walker JM. Suppression of noxious stimulus-evoked activity in the ventral posterolateral nucleus of the thalamus by a cannabinoid agonist: correlation between electrophysiological and antinociceptive effects. J. Neurosci 1996;16:6601-6611. [PubMed: 8815936]

132. Martin WJ, Tsou K, Walker JM. Cannabinoid receptor-mediated inhibition of the rat tail-flick reflex after microinjection into the rostral ventromedial medulla. Neurosci. Lett 1998;242:33-36. [PubMed: 9509998]

133. Meng ID, Manning BH, Martin WJ, Fields HL. An analgesia circuit activated by cannabinoids. Nature 1998;395:381-383. [PubMed: 9759727]

134. Marsicano G, Wotjak CT, Azad SC, Bisogno T, Rammes G, Cascio MG, Hermann H, Tang J, Hofmann C, Zieglgänsberger W, Di Marzo V, Lutz B. The endogenous cannabinoid system controls extinction of aversive memories. Nature 2002;418:530-534. [PubMed: 12152079]

135. Martin WJ, Coffin PO, Attias E, Balinsky M, Tsou K, Walker JM. Anatomical basis for cannabinoidinduced antinociception as revealed by intracerebral microinjections. Brain Res 1999;822:237-242. [PubMed: 10082902]

136. Hohmann AG, Martin WJ, Tsou K, Walker JM. Inhibition of noxious stimulus-evoked activity of spinal cord dorsal horn neurons by the cannabinoid WIN 55,212-212. Life Sci 1995;56:2111-2118. [PubMed: 7776839]

137. Walker JM, Huang SM, Strangman NM, Tsou K, Sañudo-Peña MC. Pain modulation by release of the endogenous cannabinoid anandamide. Proc. Natl. Acad. Sci. USA 1999;96:12198-12203. [PubMed: 10518599]

138. Suplita RL 2nd, Farthing JN, Gutierrez T, Hohmann AG. Inhibition of fatty-acid amide hydrolase enhances cannabinoid stress-induced analgesia: sites of action in the dorsolateral periaqueductal gray and rostral ventromedial medulla. Neuropharmacology 2005;49:1201-1209. [PubMed: 16129456]

139. Hohmann AG, Suplita RL 2nd. Endocannabinoid mechanisms of pain modulation. A.A.P.S. J 2006;8:E693-E708.

140. Petrosino S, Palazzo E, de Novellis V, Bisogno T, Rossi F, Maione S, Di Marzo V. Changes in spinal and supraspinal endocannabinoid levels in neuropathic rats. Neuropharmacology 2007;52:415-422. [PubMed: 17011598]

141. Palazzo E, de Novellis V, Petrosino S, Marabese I, Vita D, Giordano C, Di Marzo V, Mangoni GS, Rossi F, Maione S. Neuropathic pain and the endocannabinoid system in the dorsal raphe: pharmacological treatment and interactions with the serotonergic system. Eur. J. Neurosci 2006;24:2011-2020. [PubMed: 17040473]

142. de Lago E, Petrosino S, Valenti M, Morera E, Ortega-Gutierrez S, Fernandez-Ruiz J, Di Marzo V. Effect of repeated systemic administration of selective inhibitors of endocannabinoid inactivation on rat brain endocannabinoid levels. Biochem. Pharmacol 2005;70:446-452. [PubMed: 15963472]

143. Smith PB, Martin BR. Spinal mechanisms of delta 9-tetrahydrocannabinol-induced analgesia. Brain Res 1992;578:8-12. [PubMed: 1324767]

144. Welch SP, Thomas C, Patrick GS. Modulation of cannabinoid-induced antinociception after intracerebroventricular versus intrathecal administration to mice: possible mechanisms for interaction with morphine. J. Pharmacol. Exp. Ther 1995;272:310-321. [PubMed: 7815346] 
145. Yaksh TL. The antinociceptive effects of intrathecally administered levonantradol and desacetyllevonantradol in the rat. J. Clin. Pharmacol 1981;21:334S-340S. [PubMed: 6895380]

146. Hohmann AG, Tsou K, Walker JM. Cannabinoid modulation of wide dynamic range neurons in the lumbar dorsal horn of the rat by spinally administered WIN55, 212-212. Neurosci. Lett 1998;257:119-122. [PubMed: 9870334]

147. Johanek LM, Simone DA. Cannabinoid agonist, CP 55,940, prevents capsaicin-induced sensitization of spinal cord dorsal horn neurons. J. Neurophysiol 2005;93:989-997. [PubMed: 15385593]

148. Sokal DM, Elmes SJR, Kendall DA, Chapman V. Intraplantar injection of anandamide inhibits mechanically-evoked responses of spinal neurones via activation of CB2 receptors in anaesthetised rats. Neuropharmacology 2003;45:404-411. [PubMed: 12871657]

149. Richardson JD, Aanonsen L, Hargreaves KM. Hypoactivity of the spinal cannabinoid system results in NMDA-dependent hyperalgesia. J. Neurosci 1998;18:451-457. [PubMed: 9412521]

150. Lim G, Sung B, Ji RR, Mao J. Upregulation of spinal cannabinoid-1-receptors following nerve injury enhances the effects of Win 55,212-212 on neuropathic pain behaviors in rats. Pain 2003;105:275283. [PubMed: 14499445]

151. Scott DA, Wright CE, Angus JA. Evidence that CB-1 and CB-2 cannabinoid receptors mediate antinociception in neuropathic pain in the rat. Pain 2004;109:124-131. [PubMed: 15082134]

152. Elmes SJ, Jhaveri MD, Smart D, Kendall DA, Chapman V. Cannabinoid CB2 receptor activation inhibits mechanically evoked responses of wide dynamic range dorsal horn neurons in naïve rats and in rat models of inflammatory and neuropathic pain. Eur. J. Neurosci 2004;20:2311-2320. [PubMed: 15525273]

153. Kelly S, Chapman V. Selective cannabinoid CB1 receptor activation inhibits spinal nociceptive transmission in vivo. J. Neurophysiol 2001;86:3061-3064. [PubMed: 11731561]

154. Nackley AG, Zvonok AM, Makriyannis A, Hohmann AG. Activation of cannabinoid CB2 receptors suppresses C-fiber responses and windup in spinal wide dynamic range neurons in the absence and presence of inflammation. J. Neurophysiol 2004;92:3562-3574. [PubMed: 15317842]

155. Strangman NM, Walker JM. Cannabinoid WIN 55,212-2 inhibits the activity-dependent facilitation of spinal nociceptive responses. J. Neurophysiol 1999;82:472-477. [PubMed: 10400973]

156. Farquhar-Smith WP, Jaggar SI, Rice AS. Attenuation of nerve growth factor-induced visceral hyperalgesia via cannabinoid CB(1) and CB(2)-like receptors. Pain 2002;97:11-21. [PubMed: 12031775]

157. Martin WJ, Loo CM, Basbaum AI. Spinal cannabinoids are anti-allodynic in rats with persistent inflammation. Pain 1999;82:199-205. [PubMed: 10467924]

158. Nackley AG, Makriyannis A, Hohmann AG. Selective activation of cannabinoid CB(2) receptors suppresses spinal fos protein expression and pain behavior in a rat model of inflammation. Neuroscience 2003;119:747-757. [PubMed: 12809695]

159. Tsou K, Lowitz KA, Hohmann AG, Martin WJ, Hathaway CB, Bereiter DA, Walker JM. Suppression of noxious stimulus-evoked expression of Fos protein-like immunoreactivity in rat spinal cord by a selective cannabinoid agonist. Neuroscience 1996;70:791-798. [PubMed: 10627219]

160. Hohmann AG, Tsou K, Walker JM. Cannabinoid suppression of noxious heat-evoked activity in wide dynamic range neurons in the lumbar dorsal horn of the rat. J. Neurophysiol 1999;81:575583. [PubMed: 10036261]

161. Hohmann AG, Herkenham M. Regulation of cannabinoid and mu opioid receptors in rat lumbar spinal cord following neonatal capsaicin treatment. Neurosci. Lett 1998;252:13-16. [PubMed: 9756347]

162. Salio C, Doly S, Fischer J, Franzoni MF, Conrath M. Neuronal and astrocytic localization of the cannabinoid receptor-1 in the dorsal horn of the rat spinal cord. Neurosci. Lett 2002;329:13-16. [PubMed: 12161251]

163. Sagar DR, Kelly S, Millns PJ, O'Shaughnessey CT, Kendall DA, Chapman V. Inhibitory effects of $\mathrm{CB} 1$ and $\mathrm{CB} 2$ receptor agonists on responses of DRG neurons and dorsal horn neurons in neuropathic rats. Eur. J. Neurosci 2005;22:371-379. [PubMed: 16045490] 
164. Garcia-Ovejero D, Arevalo-Martin A, Petrosino S, Docagne F, Hagen C, Bisogno T, Watanabe M, Guaza C, Di Marzo V, Molina-Holgado E. The endocannabinoid system is modulated in response to spinal cord injury in rats. Neurobiol. Dis 2009;33:57-71. [PubMed: 18930143]

165. Ross RA, Coutts AA, McFarlane SM, Anavi-Goffer S, Irving AJ, Pertwee RG, MacEwan DJ, Scott RH. Actions of cannabinoid receptor ligands on rat cultured sensory neurones: implications for antinociception. Neuropharmacology 2001;40:221-232. [PubMed: 11114401]

166. Ständer S, Schmelz M, Metze D, Luger T, Rukwied R. Distribution of cannabinoid receptor 1 (CB1) and 2 (CB2) on sensory nerve fibers and adnexal structures in human skin. J. Dermatol. Sci 2005;38:177-188. [PubMed: 15927811]

167. Walczak JS, Pichette V, Leblond F, Desbiens K, Beaulieu P. Behavioral, pharmacological and molecular characterization of the saphenous nerve partial ligation: a new model of neuropathic pain. Neuroscience 2005;132:1093-1102. [PubMed: 15857713]

168. Farquhar-Smith, WP.; Rice, ASC. Peripheral mechanisms of inflammatory pain: towards the discovery of novel analgesics. In: Adams, AP.; Cashman, JN., editors. Recent advances in anaesthesia and analgesia. London: Churchill Livingstone; 2000. p. 41-60.

169. Roosterman D, Goerge T, Schneider SW, Bunnett NW, Steinhoff M. Neuronal control of skin function: the skin as a neuroimmunoendocrine organ. Physiol. Rev 2006;86:1309-1379. [PubMed: 17015491]

170. Mitrirattanakul S, Ramakul N, Guerrero AV, Matsuka Y, Ono T, Iwase H, Mackie K, Faull KF, Spigelman I. Site-specific increases in peripheral cannabinoid receptors and their endogenous ligands in a model of neuropathic pain. Pain 2006;126:102-114. [PubMed: 16844297]

171. Bridges D, Rice AS, Egertová M, Elphick MR, Winter J, Michael GJ. Localisation of cannabinoid receptor 1 in rat dorsal root ganglion using in situ hybridisation and immunohistochemistry. Neuroscience 2003;119:803-812. [PubMed: 12809701]

172. Burns TL, Ineck JR. Cannabinoid analgesia as a potential new therapeutic option in the treatment of chronic pain. Ann. Pharmacother 2006;40:251-260. [PubMed: 16449552]

173. Casanova ML, Blazquez C, Martinez-Palacio J, Villanueva C, Fernandez-Acenero MJ, Huffman JW, Jorcano JL, Guzman M. Inhibition of skin tumor growth and angiogenesis in vivo by activation of cannabinoid receptors. J. Clin. Invest 2003;111:43-50. [PubMed: 12511587]

174. Guindon J, Beaulieu P. The role of the endogenous cannabinoid system in peripheral analgesia. Current Molecular Pharmacology 2009;2:134-139. [PubMed: 20021453]

175. Ibrahim MM, Porreca F, Lai J, Albrecht PJ, Rice FL, Khodorova A, Davar G, Makriyannis A, Vanderah TW, Mata HP, Malan TP. CB2 cannabinoid receptor activation produces antinociception by stimulating peripheral release of endogenous opioids. Proc. Natl. Acad. Sci. USA 2005;102:3093-3098. [PubMed: 15705714]

176. Beaulieu P, Bisogno T, Punwar S, Farquhar-Smith WP, Ambrosino G, Di Marzo V, Rice AS. Role of the endogenous cannabinoid system in the formalin test of persistent pain in the rat. Eur. J. Pharmacol 2000;396:85-92. [PubMed: 10822060]

177. Calignano A, La Rana G, Giuffrida A, Piomelli D. Control of pain initiation by endogenous cannabinoids. Nature 1998;394:277-281. [PubMed: 9685157]

178. Guindon J, LoVerme J, De Léan A, Piomelli D, Beaulieu P. Synergistic antinociceptive effects of anandamide, an endocannabinoid, and nonsteroidal anti-inflammatory drugs in peripheral tissue: a role for endogenous fatty-acid ethanolamides? Eur. J. Pharmacol 2006;550:68-77. [PubMed: 17027744]

179. Holt S, Comelli F, Costa B, Fowler CJ. Inhibitors of fatty acid amide hydrolase reduce carrageenaninduced hind paw inflammation in pentobarbital-treated mice: comparison with indomethacin and possible involvement of cannabinoid receptors. Br. J. Pharmacol 2005;146:467-476. [PubMed: 16100529]

180. Bisogno T, Ortar G, Petrosino S, Morera E, Palazzo E, Nalli M, Maione S, Di Marzo V, Endocannabinoid Research Group. Development of a potent inhibitor of 2-arachidonoylglycerol hydrolysis with antinociceptive activity in vivo. Biochim. Biophys. Acta 2009;1791:53-60. [PubMed: 19027877]

181. Khasabova IA, Khasabov SG, Harding-Rose C, Coicou LG, Seybold BA, Lindberg AE, Steevens $\mathrm{CD}$, Simone DA, Seybold VS. A decrease in anandamide signaling contributes to the maintenance 
of cutaneous mechanical hyperalgesia in a model of bone cancer pain. J. Neurosci 2008;28:1114111152. [PubMed: 18971457]

182. Richardson JD, Aanonsen L, Hargreaves KM. SR 141716A, a cannabinoid receptor antagonist, produces hyperalgesia in untreated mice. Eur. J. Pharmacol 1997;319:R3-R4. [PubMed: 9042616]

183. Richardson JD, Kilo S, Hargreaves KM. Cannabinoids reduce hyperalgesia and inflammation via interaction with peripheral CB1 receptors. Pain 1998;75:111-119. [PubMed: 9539680]

184. Strangman NM, Patrick SL, Hohmann AG, Tsou K, Walker JM. Evidence for a role of endogenous cannabinoids in the modulation of acute and tonic pain sensitivity. Brain Res 1998;813:323-328. [PubMed: 9838180]

185. Suplita RL 2nd, Eisenstein SA, Neely MH, Moise AM, Hohmann AG. Cross-sensitization and crosstolerance between exogenous cannabinoid antinociception and endocannabinoid-mediated stressinduced analgesia. Neuropharmacology 2008;54:161-171. Move so it appears numerically between 184 and 186. [PubMed: 17714742]

186. D'Amour FE, Smith DC. A method for determining the loss of pain sensation. J. Pharmacol. Exp. Ther 1941;72:74-79.

187. Hasanein P, Javanmardi K. A potent and selective inhibitor of endocannabinoid uptake, UCM707, potentiates antinociception induced by cholestasis. Fundam. Clin. Pharmacol 2008;22:517-522. [PubMed: 18844724]

188. Adams IB, Compton DR, Martin BR. Assessment of anandamide interaction with the cannabinoid brain receptor: SR 141716A antagonism studies in mice and autoradiographic analysis of receptor binding in rat brain. J. Pharmacol. Exp. Ther 1998;284:1209-1217. [PubMed: 9495885]

189. Haller VL, Stevens DL, Welch SP. Modulation of opioids via protection of anandamide degradation by fatty acid amide hydrolase. Eur. J. Pharmacol 2008;600:50-58. [PubMed: 18762181]

190. Smith PB, Compton DR, Welch SP, Razdan RK, Mechoulam R, Martin BR. The pharmacological activity of anandamide, a putative endogenous cannabinoid, in mice. J. Pharmacol. Exp. Ther 1994;270:219-227. [PubMed: 8035318]

191. Wiley JL, Razdan RK, Martin BR. Evaluation of the role of the arachidonic acid cascade in anandamide's in vivo effects in mice. Life Sci 2006;80:24-35. [PubMed: 16978656]

192. Costa B, Vailati S, Colleoni M. SR 141716A, a cannabinoid receptor antagonist, reverses the behavioural effects of anandamide-treated rats. Behav. Pharmacol 1999;10:327-331. [PubMed: 10780247]

193. Mason DJ Jr, Lowe J, Welch SP. Cannabinoid modulation of dynorphin A: correlation to cannabinoid-induced antinociception. Eur. J. Pharmacol 1999;378:237-248. [PubMed: 10493099]

194. Welch SP, Huffman JW, Lowe J. Differential blockade of the antinociceptive effects of centrally administered cannabinoids by SR141716A. J. Pharmacol. Exp. Ther 1998;286:1301-1308. [PubMed: 9732392]

195. Pertwee RG. Pharmacological actions of cannabinoids. Handb. Exp. Pharmacol 2005;168:1-51. [PubMed: 16596770]

196. Compton DR, Martin BR. The effect of the enzyme inhibitor phenylmethylsulfonyl fluoride on the pharmacological effect of anandamide in the mouse model of cannabimimetic activity. J. Pharmacol. Exp. Ther 1997;283:1138-1143. [PubMed: 9399986]

197. Hasanein P, Shahidi S, Komaki A, Mirazi N. Effects of URB597 as an inhibitor of fatty acid amide hydrolase on modulation of nociception in a rat model of cholestasis. Eur. J. Pharmacol 2008;591:132-135. [PubMed: 18593578]

198. Lichtman AH, Shelton CC, Advani T, Cravatt BF. Mice lacking fatty acid amide hydrolase exhibit a cannabinoid receptor-mediated phenotypic hypoalgesia. Pain 2004;109:319-327. [PubMed: 15157693]

199. van Eick AJ. A change in the response of the mouse in the "hot plate" analgesia-test, owing to a central action of atropine and related compounds. Acta Physiol. Pharmacol. Neerl 1967;14:499500. [PubMed: 5582715]

200. de Lago E, Fernández-Ruiz J, Ortega-Gutiérrez S, Viso A, López-Rodríguez ML, Ramos JA. UCM707, a potent and selective inhibitor of endocannabinoid uptake, potentiates hypokinetic and antinociceptive effects of anandamide. Eur. J. Pharmacol 2002;449:99-103. [PubMed: 12163112] 
201. de Lago E, Ligresti A, Ortar G, Morera E, Cabranes A, Pryce G, Bifulco M, Baker D, FernandezRuiz J, Di Marzo V. In vivo pharmacological actions of two novel inhibitors of anandamide cellular uptake. Eur. J. Pharmacol 2004;484:249-257. [PubMed: 14744610]

202. Calignano A, La Rana G, Piomelli D. Antinociceptive activity of the endogenous fatty acid amide, palmitylethanolamide. Eur. J. Pharmacol 2001;419:191-198. [PubMed: 11426841]

203. Welch SP, Dunlow LD, Patrick GS, Razdan RK. Characterization of anandamide-and fluoroanandamide-induced antinociception and cross-tolerance to delta 9-THC after intrathecal administration to mice: blockade of delta 9-THC-induced antinociception. J. Pharmacol. Exp. Ther 1995;273:1235-1244. [PubMed: 7791096]

204. Kathuria S, Gaetani S, Fegley D, Valiño F, Duranti A, Tontini A, Mor M, Tarzia G, La Rana G, Calignano A, Giustino A, Tattoli M, Palmery M, Cuomo V, Piomelli D. Modulation of anxiety through blockade of anandamide hydrolysis. Nat. Med 2003;9:76-81. [PubMed: 12461523]

205. Hargreaves K, Dubner R, Brown F, Flores C, Joris. A new and sensitive method for measuring thermal nociception in cutaneous hyperalgesia. Pain 1988;32:77-88. [PubMed: 3340425]

206. Sit SY, Conway C, Bertekap R, Xie K, Bourin C, Burris K, Deng H. Novel inhibitors of fatty acid amide hydrolase. Bioorg. Med. Chem. Lett 2007;17:3287-3291. [PubMed: 17459705]

207. Smith FL, Fujimori K, Lowe J, Welch SP. Characterization of delta9-tetrahydrocannabinol and anandamide antinociception in nonarthritic and arthritic rats. Pharmacol. Biochem. Behav 1998;60:183-191. [PubMed: 9610941]

208. Randall LO, Selitto JJ. A method for measurement of analgesic activity on inflamed tissue. Arch. Int. Pharmacodyn. Ther 1957;111:409-419. [PubMed: 13471093]

209. Dubuisson D, Dennis SG. The formalin test: a quantitative study of the analgesic effects of morphine, meperidine, and brain stem stimulation in rats and cats. Pain 1977;4:161-174. [PubMed: 564014]

210. Tjölsen A, Berge OG, Hunskaar S, Rosland JH, Hole K. The formalin test: an evaluation of the method. Pain 1992;51:5-17. [PubMed: 1454405]

211. Coderre TJ, Katz J. Peripheral and central hyperexcitability: differential signs and symptoms in persistent pain. Behav. Brain Sci 1997;20:404-419. discussion 435-513. [PubMed: 10097003]

212. Coderre TJ, Melzack R. The contribution of excitatory amino acids to central sensitization and persistent nociception after formalin-induced tissue injury. J. Neurosci 1992;12:3665-3670. [PubMed: 1326610]

213. Puig S, Sorkin LS. Formalin-evoked activity in identified primary afferent fibers: systemic lidocaine suppresses phase-2 activity. Pain 1996;64:345-355. [PubMed: 8740613]

214. La Rana G, Russo R, Campolongo P, Bortolato M, Mangieri RA, Cuomo V, Iacono A, Raso GM, Meli R, Piomelli D, Calignano A. Modulation of neuropathic and inflammatory pain by the endocannabinoid transport inhibitor AM404 [N-(4-hydroxyphenyl)-eicosa-5,8,11,14tetraenamide]. J. Pharmacol. Exp. Ther 2006;317:1365-1371. [PubMed: 16510698]

215. Maione S, Morera E, Marabese I, Ligresti A, Luongo L, Ortar G, Di Marzo V. Antinociceptive effects of tetrazole inhibitors of endocannabinoid inactivation: cannabinoid and non-cannabinoid receptor-mediated mechanisms. Br. J. Pharmacol 2008;155:775-782. [PubMed: 18660824]

216. Guindon J, De Léan A, Beaulieu P. Local interactions between anandamide, an endocannabinoid, and ibuprofen, a nonsteroidal anti-inflammatory drug, in acute and inflammatory pain. Pain 2006;121:85-93. [PubMed: 16480822]

217. Guindon J, Desroches J, Beaulieu P. The antinociceptive effects of intraplantar injections of 2arachidonoyl glycerol are mediated by cannabinoid CB2 receptors. Br. J. Pharmacol 2007;150:693701. [PubMed: 17179944]

218. Ates M, Hamza M, Seidel K, Kotalla CE, Ledent C, Gühring H. Intrathecally applied flurbiprofen produces an endocannabinoid-dependent antinociception in the rat formalin test. Eur. J. Neurosci 2003;17:597-604. [PubMed: 12581177]

219. Maione S, De Petrocellis L, de Novellis V, Moriello AS, Petrosino S, Palazzo E, Rossi FS, Woodward DF, Di Marzo V. Analgesic actions of N-arachidonoyl-serotonin, a fatty acid amide hydrolase inhibitor with antagonistic activity at vanilloid TRPV1 receptors. Br. J. Pharmacol 2007;150:766781. [PubMed: 17279090] 
220. Ortar G, Cascio MG, De Petrocellis L, Morera E, Rossi F, Schiano-Moriello A, Nalli M, de Novellis V, Woodward DF, Maione S, Di Marzo V. New N-arachidonoylserotonin analogues with potential "dual" mechanism of action against pain. J. Med. Chem 2007;50:6554-6569. [PubMed: 18027904]

221. Guindon J, LoVerme J, Piomelli D, Beaulieu P. The antinociceptive effects of local injections of propofol in rats are mediated in part by cannabinoid CB1 and CB2 receptors. Anesth. Analg 2007;104:1563-1569. [PubMed: 17513659]

222. Honoré P, Chapman V, Buritova J, Besson JM. When is the maximal effect of pre-administered systemic morphine on carrageenin evoked spinal c-Fos expression in the rat? Brain Res 1995;705:91-96. [PubMed: 8821738]

223. Richardson JD, Aanonsen L, Hargreaves KM. Antihyperalgesic effects of spinal cannabinoids. Eur. J. Pharmacol 1998;345:145-153. [PubMed: 9600630]

224. Tuboly G, Kekesi G, Nagy E, Benedek G, Horvath G. The antinociceptive interaction of anandamide and adenosine at the spinal level. Pharmacol. Biochem. Behav 2009;91:374-379. [PubMed: 18760296]

225. Jhaveri MD, Richardson D, Robinson I, Garle MJ, Patel A, Sun Y, Sagar DR, Bennett AJ, Alexander SP, Kendall DA, Barrett DA, Chapman V. Inhibition of fatty acid amide hydrolase and cyclooxygenase-2 increases levels of endocannabinoid related molecules and produces analgesia via peroxisome proliferator-activated receptor-alpha in a model of inflammatory pain. Neuropharmacology 2008;55:85-93. [PubMed: 18534634]

226. Sagar DR, Kendall DA, Chapman V. Inhibition of fatty acid amide hydrolase produces PPAR-alphamediated analgesia in a rat model of inflammatory pain. Br. J. Pharmacol 2008;155:1297-1306. [PubMed: 18724387]

227. Karbarz MJ, Luo L, Chang L, Tham CS, Palmer JA, Wilson SJ, Wennerholm ML, Brown SM, Scott BP, Apodaca RL, Keith JM, Wu J, Breitenbucher JG, Chaplan SR, Webb M. Biochemical and biological properties of 4-(3-phenyl-[1,2,4] thiadiazol-5-yl)-piperazine-1-carboxylic acid phenylamide, a mechanism-based inhibitor of fatty acid amide hydrolase. Anesth. Analg 2009;108:316-329. [PubMed: 19095868]

228. Comelli F, Giagnoni G, Bettoni I, Colleoni M, Costa B. The inhibition of monoacylglycerol lipase by URB602 showed an anti-inflammatory and anti-nociceptive effect in a murine model of acute inflammation. Br. J. Pharmacol 2007;152:787-794. [PubMed: 17700715]

229. Magrioti V, Naxakis G, Hadjipavlou-Litina D, Makriyannis A, Kokotos G. A novel monoacylglycerol lipase inhibitor with analgesic and anti-inflammatory activity. Bioorg. Med. Chem. Lett 2008;18:5424-5427. [PubMed: 18819796]

230. Simone DA, Ngeow JY, Putterman GJ, LaMotte RH. Hyperalgesia to heat after intradermal injection of capsaicin. Brain Res 1987;418:201-203. [PubMed: 3664271]

231. Gilchrist HD, Allard BL, Simone DA. Enhanced withdrawal responses to heat and mechanical stimuli following intraplantar injection of capsaicin in rats. Pain 1996;67:179-188. [PubMed: 8895246]

232. Iadarola MJ, Brady LS, Draisci G, Dubner R. Enhancement of dynorphin gene expression in spinal cord following experimental inflammation: stimulus specificity, behavioral parameters and opioid receptor binding. Pain 1988;35:313-326. [PubMed: 2906426]

233. Ren K, Dubner R. Inflammatory models of pain and hyperalgesia. ILAR J 1999;40:111-118. [PubMed: 11406689]

234. Stein C, Millan MJ, Herz A. Unilateral inflammation of the hindpaw in rats as a model of prolonged noxious stimulation: alterations in behavior and nociceptive thresholds. Pharmacol. Biochem. Behav 1988;31 455-51.

235. Walker KM, Urban L, Medhurst SJ, Patel S, Panesar M, Fox AJ, McIntyre P. The VR1 antagonist capsazepine reverses mechanical hyperalgesiain models of inflammatory and neuropathic pain. J. Pharmacol. Exp. Ther 2003;304:56-62. [PubMed: 12490575]

236. Jayamanne A, Greenwood R, Mitchell VA, Aslan S, Piomelli D, Vaughan CW. Actions of the FAAH inhibitor URB597 in neuropathic and inflammatory chronic pain models. Br. J. Pharmacol 2006;147:281-288. [PubMed: 16331291] 
237. Mitchell VA, Greenwood R, Jayamanne A, Vaughan CW. Actions of the endocannabinoid transport inhibitor AM404 in neuropathic and inflammatory pain models. Clin. Exp. Pharmacol. Physiol 2007;34:1186-1190. [PubMed: 17880375]

238. Farquhar-Smith WP, Rice AS. A novel neuroimmune mechanism in cannabinoid-mediated attenuation of nerve growth factor-induced hyperalgesia. Anesthesiology 2003;99:1391-1401. [PubMed: 14639155]

239. Bennett GJ, Xie YK. A peripheral mononeuropathy in rat that produces disorders of pain sensation like those seen in man. Pain 1988;33:87-107. [PubMed: 2837713]

240. Seltzer Z, Dubner R, Shir Y. A novel behavioral model of neuropathic pain disorders produced in rats by partial sciatic nerve injury. Pain 1990;43:205-218. [PubMed: 1982347]

241. Kim SH, Chung JM. An experimental model for peripheral neuropathy produced by segmental spinal nerve ligation in the rat. Pain 1992;50:355-363. [PubMed: 1333581]

242. Guindon J, Walczak JS, Beaulieu P. Recent advances in the pharmacological management of pain. Drugs 2007;67:2121-2133. [PubMed: 17927280]

243. Costa B, Siniscalco D, Trovato AE, Comelli F, Sotgiu ML, Colleoni M, Maione S, Rossi F, Giagnoni G. AM404, an inhibitor of anandamide uptake, prevents pain behaviour and modulates cytokine and apoptotic pathways in a rat model of neuropathic pain. Br. J. Pharmacol 2006;148:1022-1032. [PubMed: 16770320]

244. La Rana G, Russo R, D'Agostino G, Sasso O, Raso GM, Iacono A, Meli R, Piomelli D, Calignano A. AM404, an anandamide transport inhibitor, reduces plasma extravasation in a model of neuropathic pain in rat: role for cannabinoid receptors. Neuropharmacology 2008;54:521-529. [PubMed: 18093621]

245. Russo R, LoVerme J, La Rana G, Compton TR, Parrott J, Duranti A, Tontini A, Mor M, Tarzia G, Calignano A, Piomelli D. The fatty acid amide hydrolase inhibitor URB597 (cyclohexylcarbamic acid 3'-carbamoylbiphenyl-3-yl ester) reduces neuropathic pain after oral administration in mice. J. Pharmacol. Exp. Ther 2007;322:236-242. [PubMed: 17412883]

246. Guindon J, Beaulieu P. Antihyperalgesic effects of local injections of anandamide, ibuprofen, rofecoxib and their combinations in a model of neuropathic pain. Neuropharmacology 2006;50:814-823. [PubMed: 16442133]

247. Helyes Z, Németh J, Thán M, Bölcskei K, Pintér E, Szolcsányi J. Inhibitory effect of anandamide on resiniferatoxin-induced sensory neuropeptide release in vivo and neuropathic hyperalgesia in the rat. Life Sci 2003;73:2345-2353. [PubMed: 12941436]

248. Desroches J, Guindon J, Lambert C, Beaulieu P. Modulation of the anti-nociceptive effects of 2arachidonoyl glycerol by peripherally administered FAAH and MGL inhibitors in a neuropathic pain model. Br. J. Pharmacol 2008;155:913-924. [PubMed: 18695638]

249. Jhaveri MD, Richardson D, Kendall DA, Barrett DA, Chapman V. Analgesic effects of fatty acid amide hydrolase inhibition in a rat model of neuropathic pain. J. Neurosci 2006;26:13318-13327. [PubMed: 17182782]

250. Timmons A, Seierstad M, Apodaca R, Epperson M, Pippel D, Brown S, Chang L, Scott B, Webb M, Chaplan SR, Breitenbucher JG. Novel ketooxazole based inhibitors of fatty acid amide hydrolase (FAAH). Bioorg. Med. Chem. Lett 2008;18:2109-2113. [PubMed: 18289847]

251. Ben-Shabat S, Fride E, Sheskin T, Tamiri T, Rhee MH, Vogel Z, Bisogno T, De Petrocellis L, Di Marzo V, Mechoulam R. An entourage effect: inactive endogenous fatty acid glycerol esters enhance 2-arachidonoyl-glycerol cannabinoid activity. Eur J Pharmacol 1998;353:23-31. [PubMed: 9721036]

252. Lo Verme J, Fu J, Astarita G, La Rana G, Russo R, Calignano A, Piomelli D. The nuclear receptor peroxisome proliferator-activated receptor-alpha mediates the anti-inflammatory actions of palmitoylethanolamide. Mol. Pharmacol 2005;67:15-19. [PubMed: 15465922]

253. LoVerme J, Russo R, La Rana G, Fu J, Farthing J, Mattace-Raso G, Meli R, Hohmann A, Calignano A, Piomelli D. Rapid broad-spectrum analgesia through activation of peroxisome proliferatoractivated receptor-alpha. J. Pharmacol. Exp. Ther 2006;319:1051-1061. [PubMed: 16997973]

254. Sun Y, Alexander SP, Garle MJ, Gibson CL, Hewitt K, Murphy SP, Kendall DA, Bennett AJ. Cannabinoid activation of PPAR alpha; a novel neuroprotective mechanism. Br. J. Pharmacol 2007;152:734-743. [PubMed: 17906680] 
255. Russo R, LoVerme J, La Rana G, D'Agostino G, Sasso O, Calignano A, Piomelli D. Synergistic antinociception by the cannabinoid receptor agonist anandamide and the PPAR-alpha receptor agonist GW7647. Eur. J. Pharmacol 2007;566:117-119. [PubMed: 17434479]

256. Adams IB, Ryan W, Singer M, Thomas BF, Compton DR, Razdan RK, Martin BR. Evaluation of cannabinoid receptor binding and in vivo activities for anandamide analogs. J. Pharmacol. Exp. Ther 1995;273:1172-1181. [PubMed: 7791088]

257. Raffa RB Jr, Stone DJ, Hipp SJ. Differential cholera-toxin sensitivity of supraspinal antinociception induced by the cannabinoid agonists delta9-THC, WIN 55,212-2 and anandamide in mice. Neurosci. Lett 1999;263:29-32. [PubMed: 10218903]

258. Ligresti A, Cascio MG, Pryce G, Kulasegram S, Beletskaya I, De Petrocellis L, Saha B, Mahadevan A, Visintin C, Wiley JL, Baker D, Martin BR, Razdan RK, Di Marzo V. New potent and selective inhibitors of anandamide reuptake with antispastic activity in a mouse model of multiple sclerosis. Br. J. Pharmacol 2006;147:83-91. [PubMed: 16284631]

259. Jaggar SI, Hasnie FS, Sellaturay S, Rice AS. The anti-hyperalgesic actions of the cannabinoid anandamide and the putative CB2 receptor agonist palmitoylethanolamide in visceral and somatic inflammatory pain. Pain 1998;76:189-199. [PubMed: 9696473] 

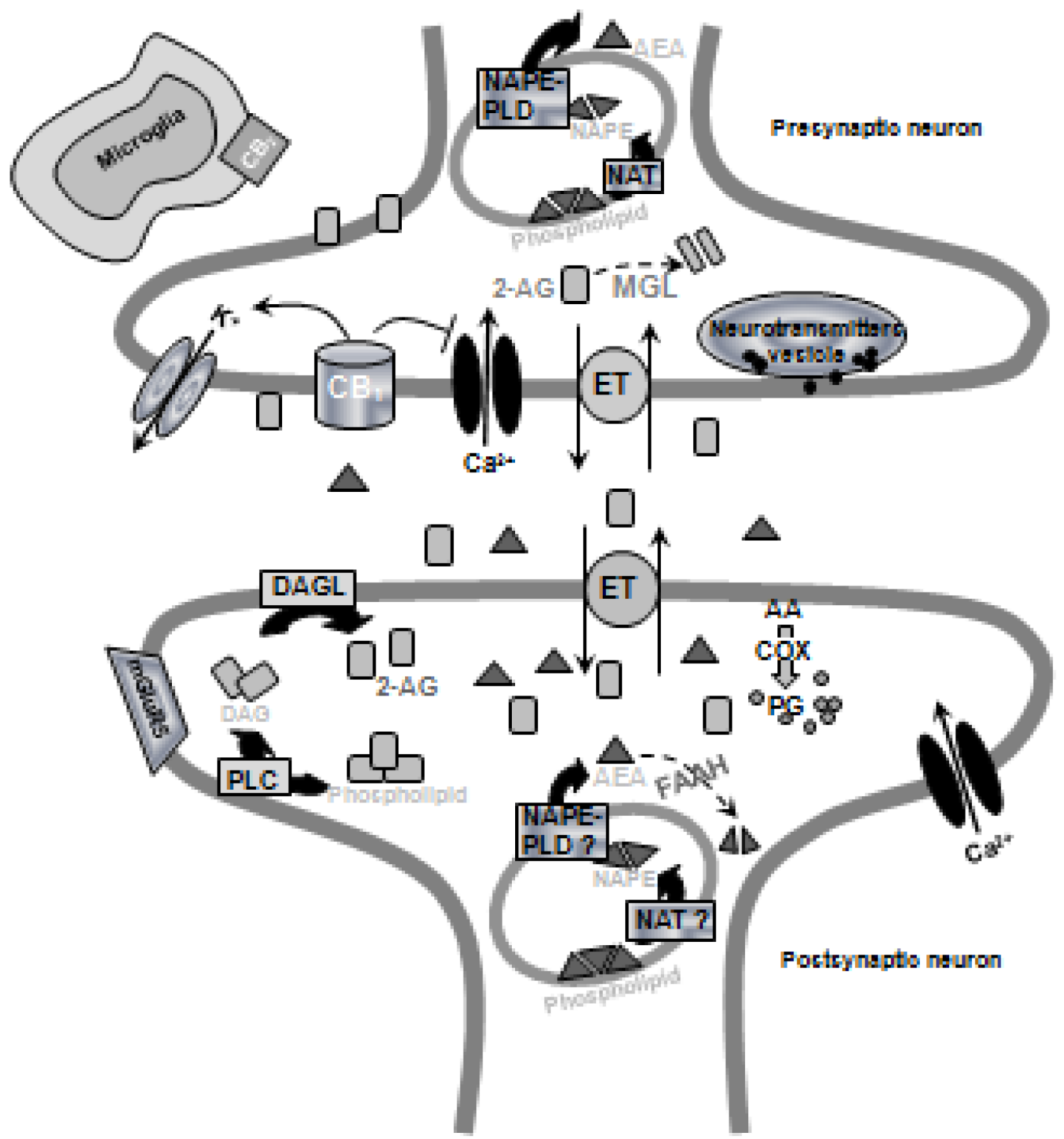

Figure 1.

Formation and inactivation of anandamide and 2-arachidonoylglycerol 

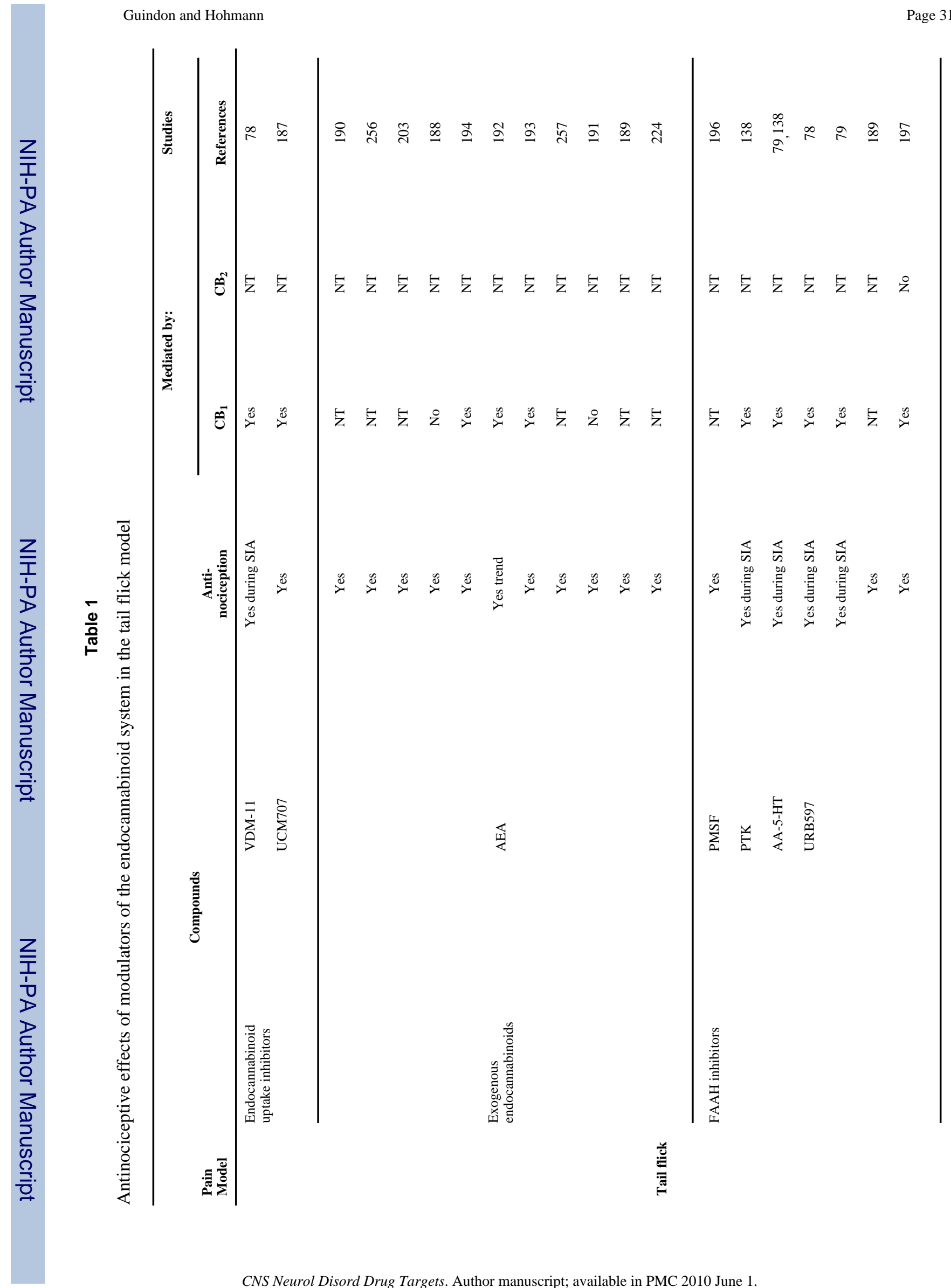

CNS Neurol Disord Drug Targets. Author manuscript; available in PMC 2010 June 1. 


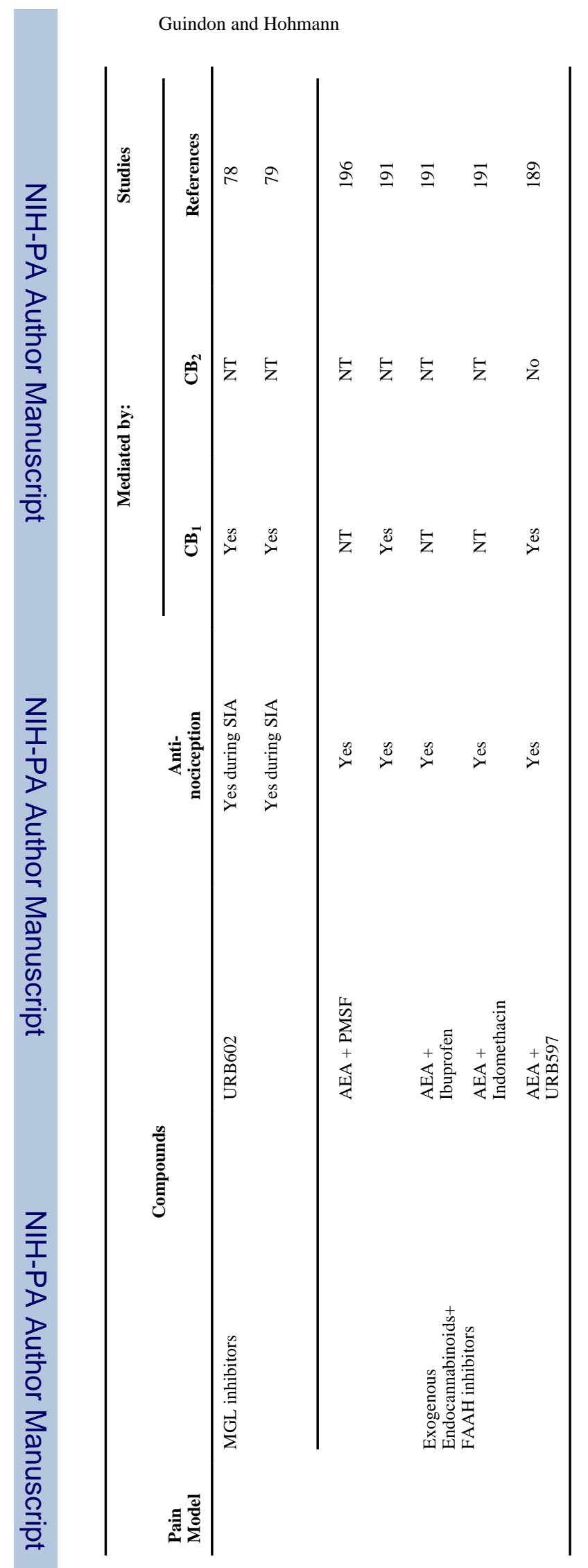

Page 32 


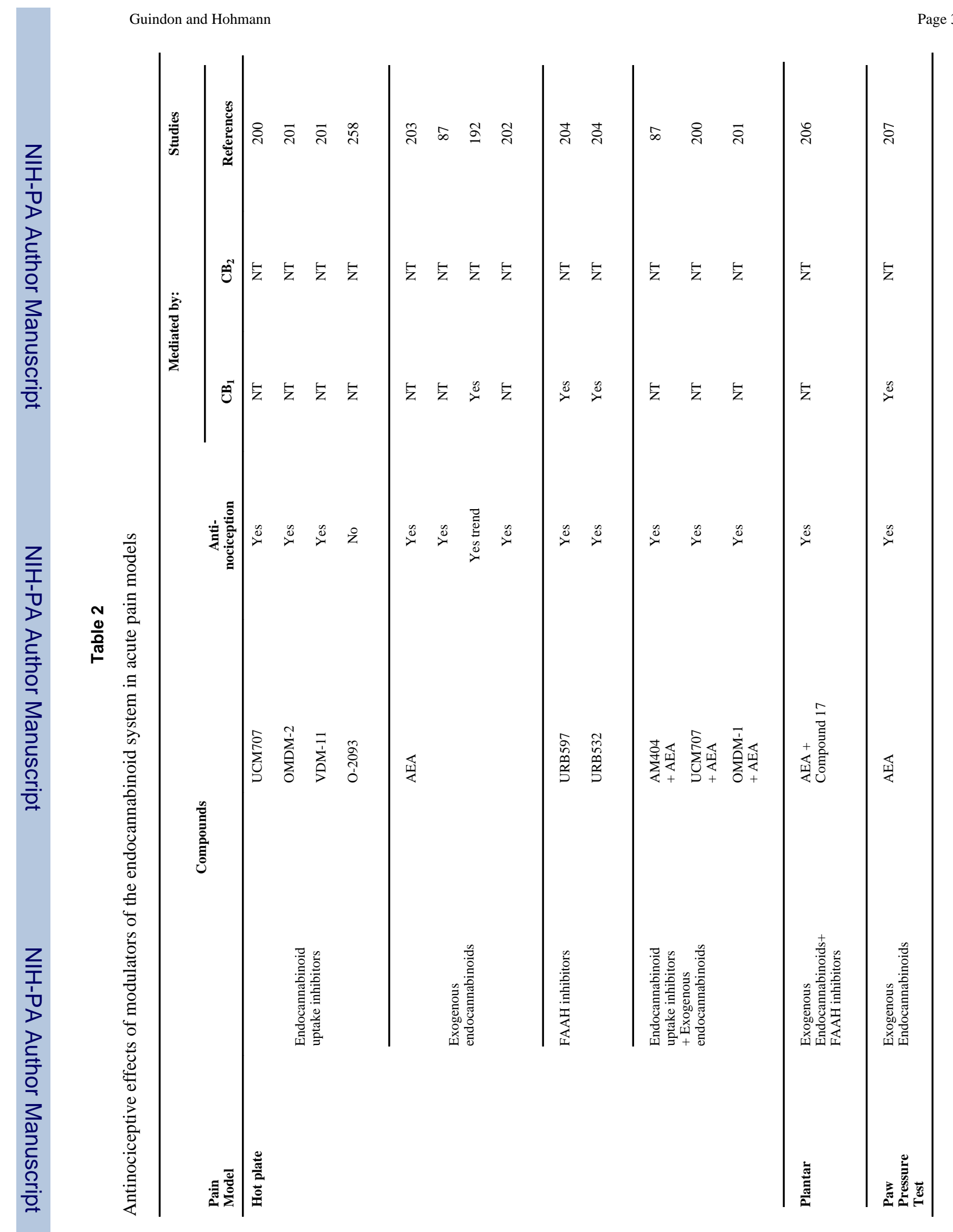

CNS Neurol Disord Drug Targets. Author manuscript; available in PMC 2010 June 1. 


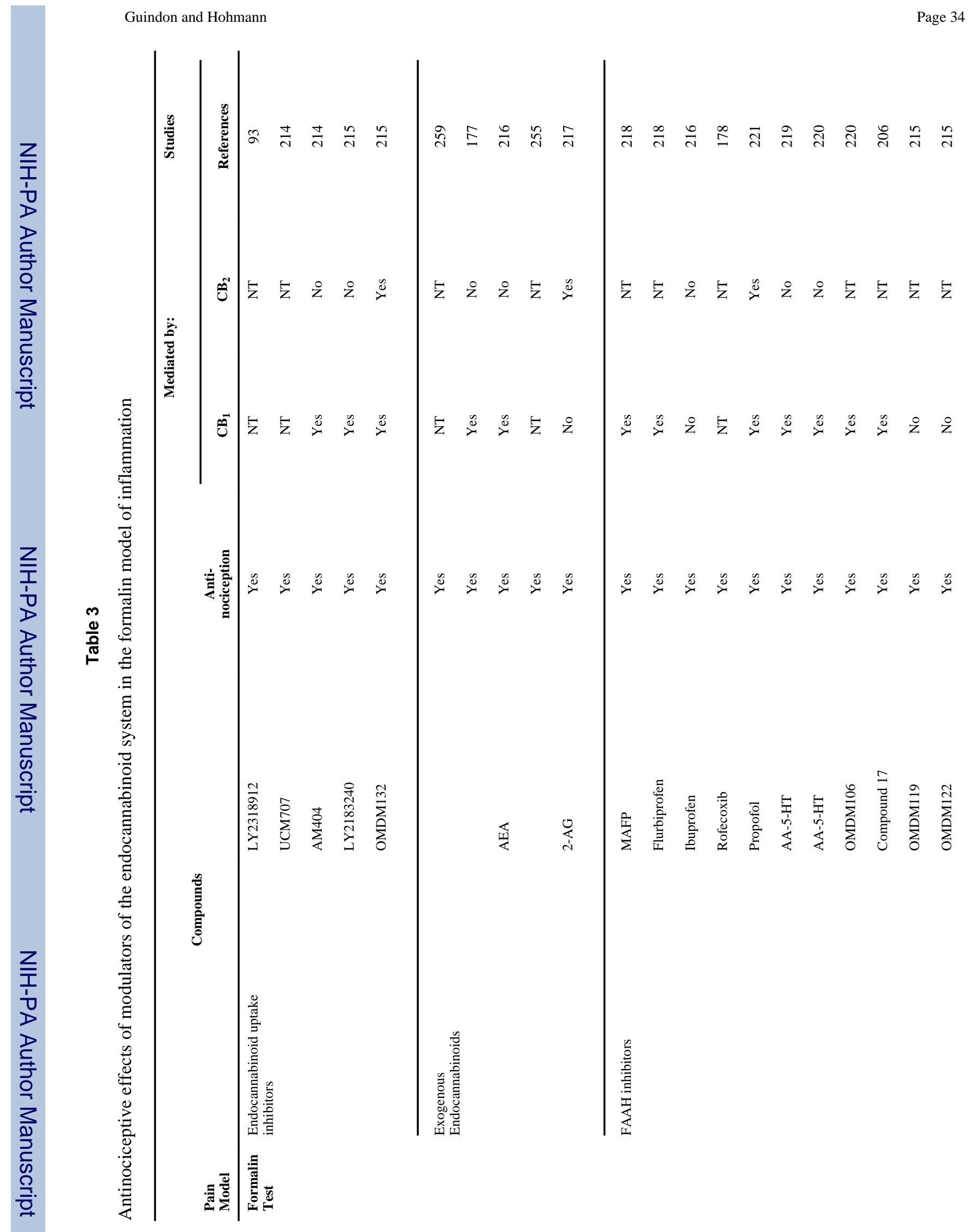

CNS Neurol Disord Drug Targets. Author manuscript; available in PMC 2010 June 1. 


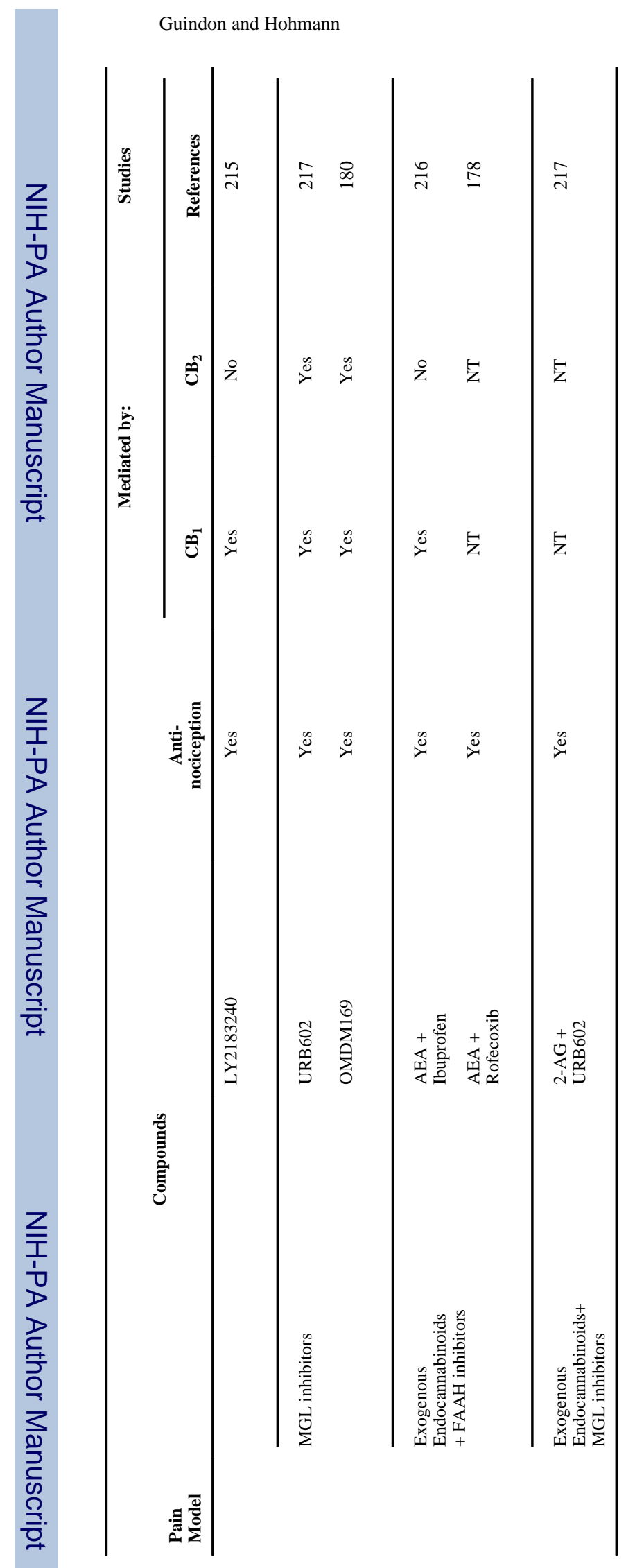

CNS Neurol Disord Drug Targets. Author manuscript; available in PMC 2010 June 1. 


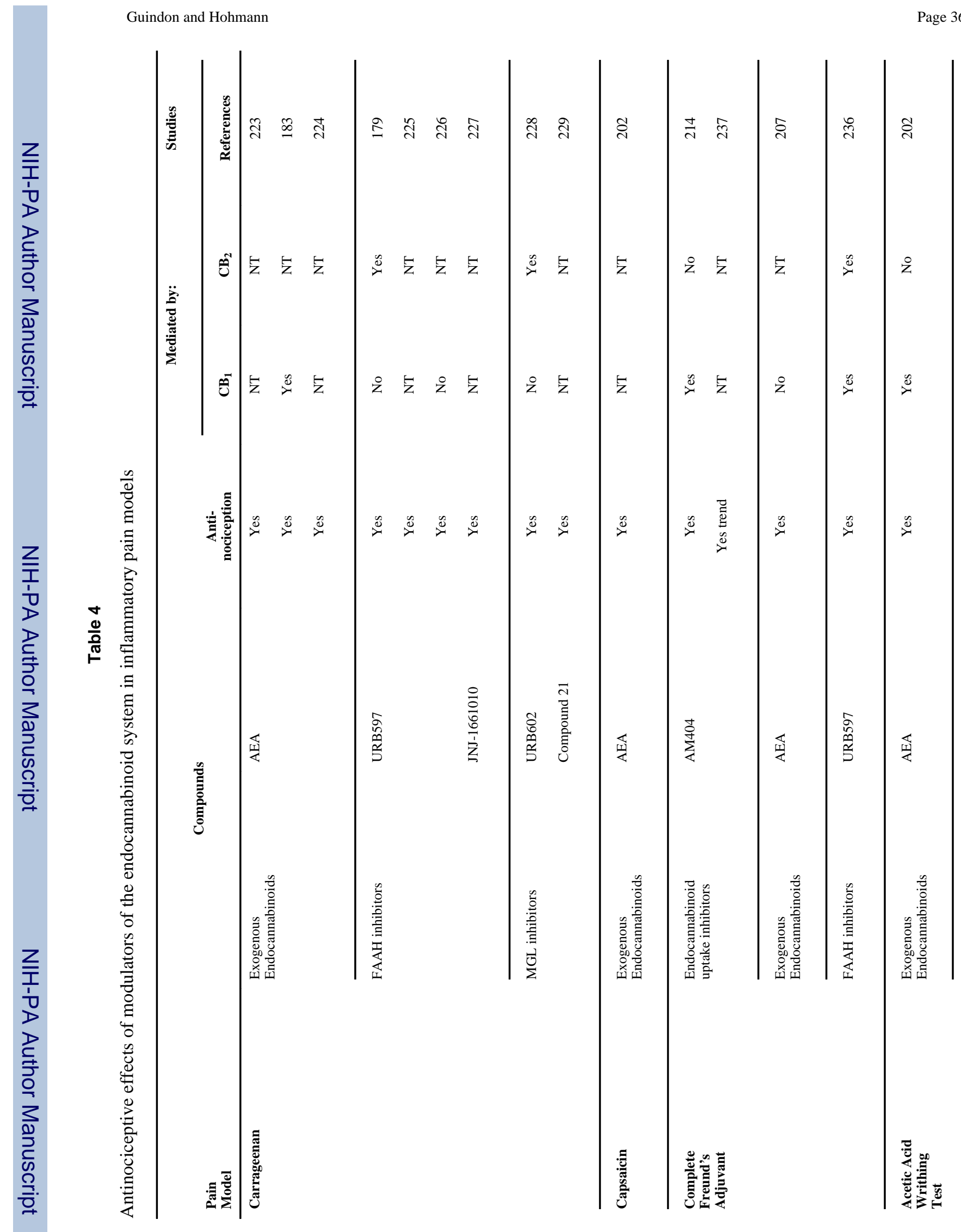




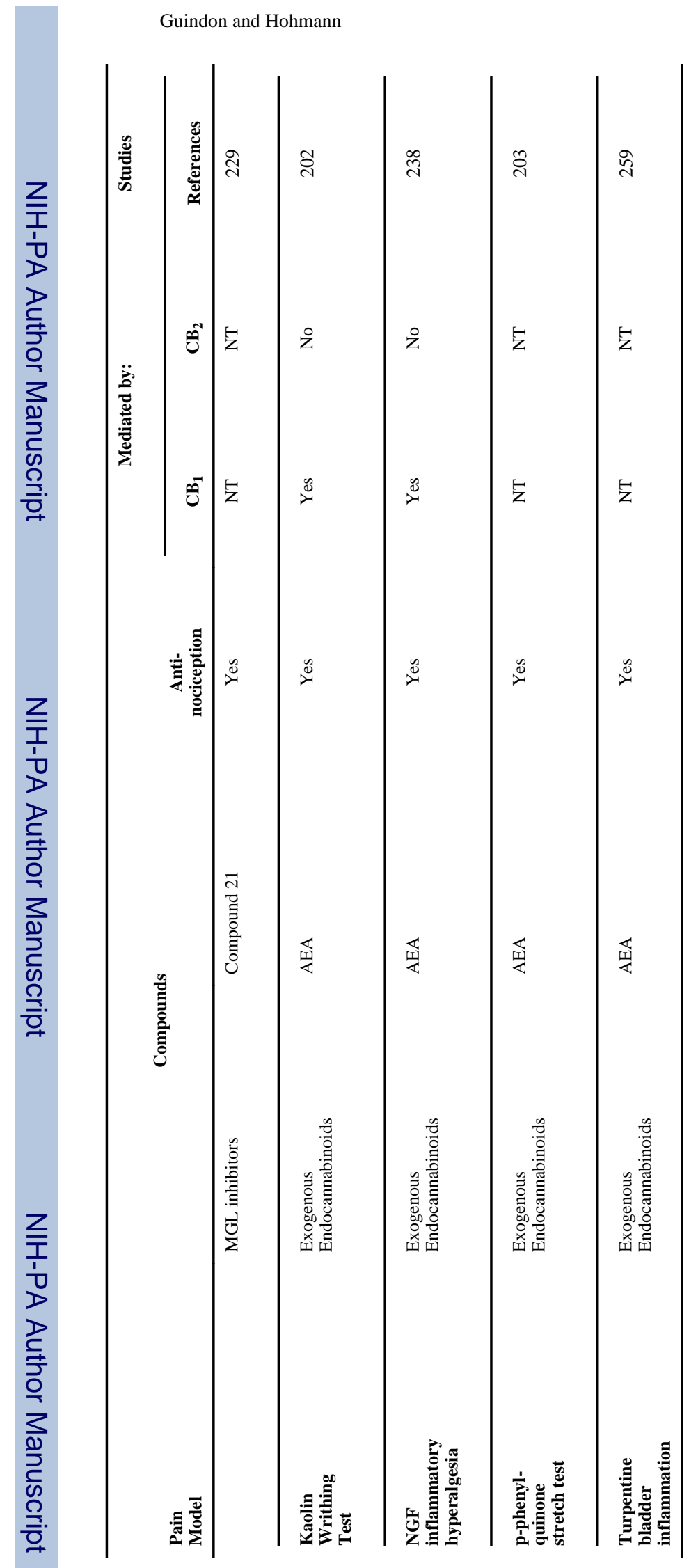

CNS Neurol Disord Drug Targets. Author manuscript; available in PMC 2010 June 1. 


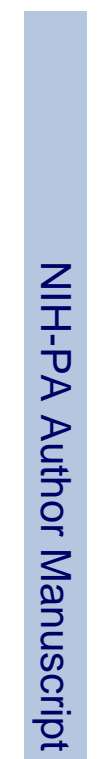

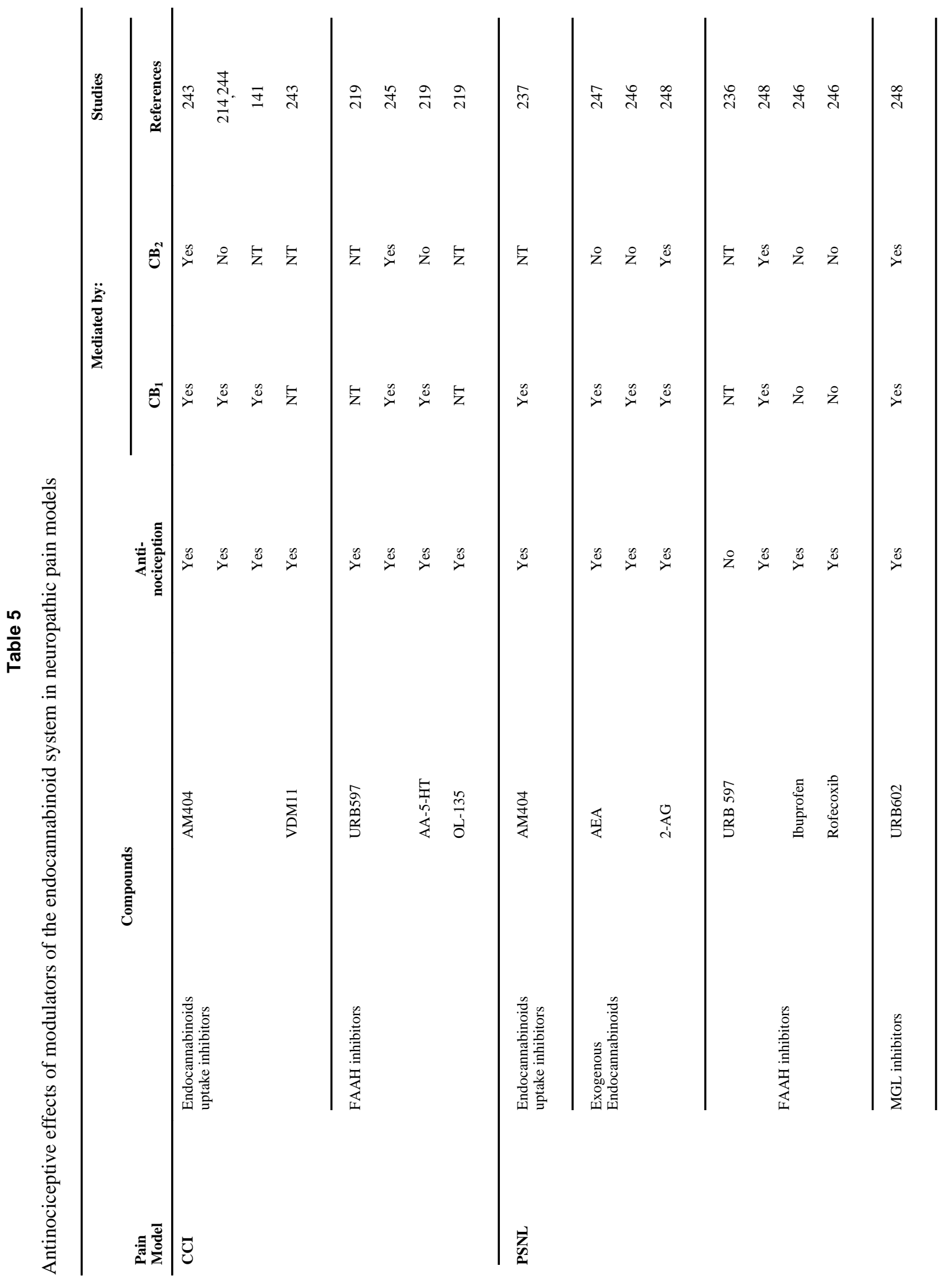




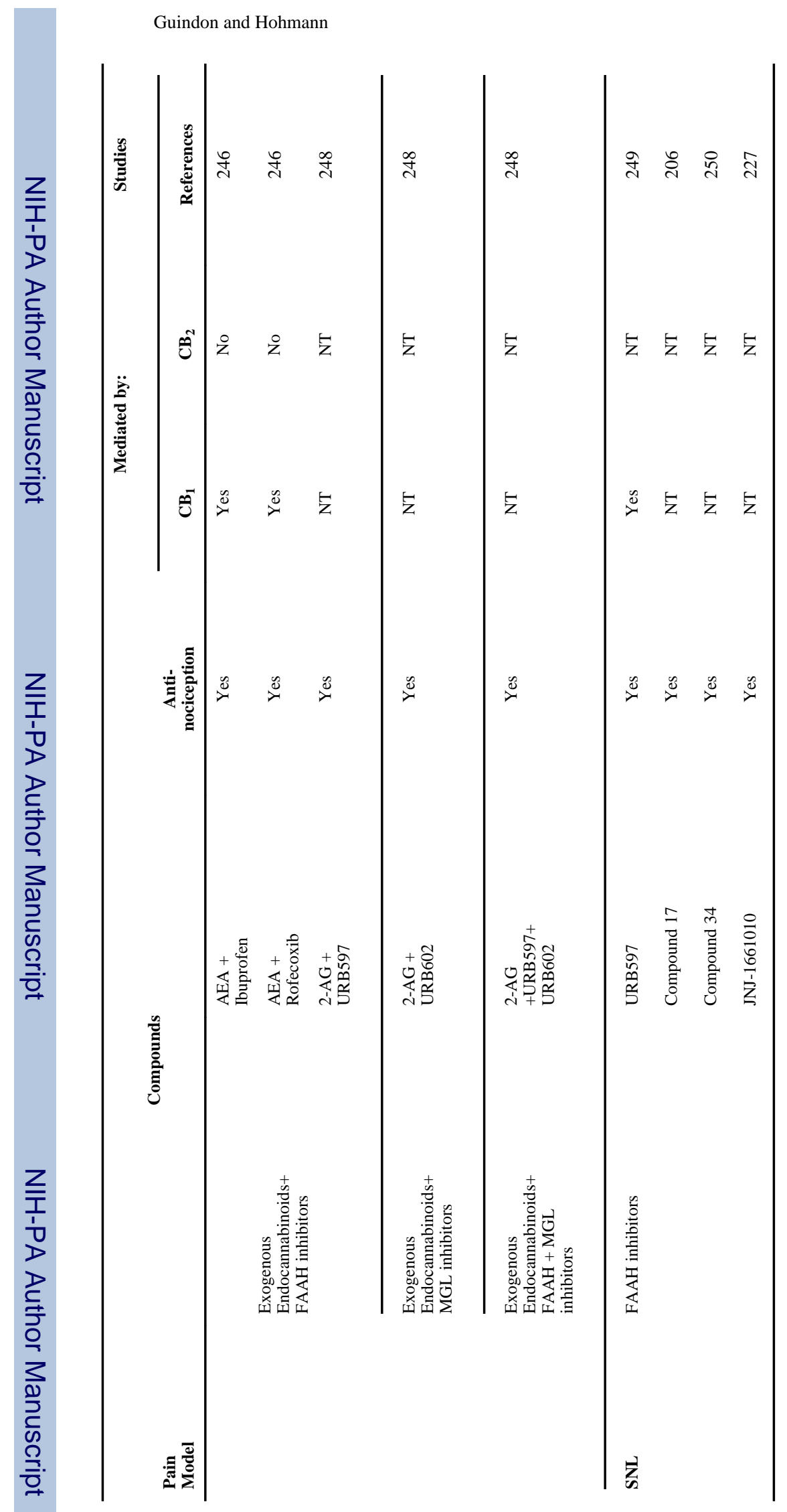

CNS Neurol Disord Drug Targets. Author manuscript; available in PMC 2010 June 1. 